See discussions, stats, and author profiles for this publication at: https://www.researchgate.net/publication/342362476

\title{
Microbial Community Structure Along a Horizontal Oxygen Gradient in a Costa Rican Volcanic Influenced Acid Rock Drainage System
}

Article in Microbial Ecology · June 2020

DOI: 10.1007/500248-020-01530-9

\section{CITATIONS}

9 authors, including:

Alejandro Arce Rodríguez

Helmholtz Centre for Infection Research

21 PUBLICATIONS 422 CITATIONS

SEE PROFILE

Roberto Avendaño

National Center for Biotechnological Innovations (CENIBiot)

11 PUBLICATIONS 72 CITATIONS

SEE PROFILE

Some of the authors of this publication are also working on these related projects:

Políticas de Ciencia, Tecnología e Innovación View project

Biodiversity and Ecology of Aquatic Fungi and Oomycetes View project

\section{READS}

91

Fernando Puente-Sánchez

National Center for Biotechnology (CNB)

51 PUBLICATIONS 271 CITATIONS

SEE PROFILE

Eduardo Libby

University of Costa Rica

42 PUBLICATIONS 1,473 CITATIONS

SEE PROFILE 


\title{
Microbial Community Structure Along a Horizontal Oxygen Gradient in a Costa Rican Volcanic Influenced Acid Rock Drainage System
}

\author{
Alejandro Arce-Rodríguez ${ }^{1,2}$ • Fernando Puente-Sánchez ${ }^{3} \cdot$ Roberto Avendaño ${ }^{4}$. Eduardo Libby ${ }^{5}$. \\ Raúl Mora-Amador ${ }^{6,7}$ - Keilor Rojas-Jimenez ${ }^{8}$ - María Martínez ${ }^{9}$ • Dietmar H. Pieper ${ }^{1}$ - Max Chavarría ${ }^{4,5,10}$
}

Received: 27 June 2019 / Accepted: 17 May 2020

(C) Springer Science+Business Media, LLC, part of Springer Nature 2020

\begin{abstract}
We describe the geochemistry and microbial diversity of a pristine environment that resembles an acid rock drainage (ARD) but it is actually the result of hydrothermal and volcanic influences. We designate this environment, and other comparable sites, as volcanic influenced acid rock drainage (VARD) systems. The metal content and sulfuric acid in this ecosystem stem from the volcanic milieu and not from the product of pyrite oxidation. Based on the analysis of 16S rRNA gene amplicons, we report the microbial community structure in the pristine San Cayetano Costa Rican VARD environment ( $\mathrm{pH}=2.94-3.06$, sulfate $\sim 0.87-$ $1.19 \mathrm{~g} \mathrm{~L}^{-1}$, iron $\sim 35-61 \mathrm{mg} \mathrm{L}^{-1}$ (waters), and $\sim 8-293 \mathrm{~g} \mathrm{~kg}^{-1}$ (sediments)). San Cayetano was found to be dominated by microorganisms involved in the geochemical cycling of iron, sulfur, and nitrogen; however, the identity and abundance of the species changed with the oxygen content $\left(0.40-6.06 \mathrm{mg} \mathrm{L}^{-1}\right)$ along the river course. The hypoxic source of San Cayetano is dominated by a putative anaerobic sulfate-reducing Deltaproteobacterium. Sulfur-oxidizing bacteria such as Acidithiobacillus or Sulfobacillus are found in smaller proportions with respect to typical ARD. In the oxic downstream, we identified aerobic ironoxidizers (Leptospirillum, Acidithrix, Ferrovum) and heterotrophic bacteria (Burkholderiaceae bacterium, Trichococcus, Acidocella). Thermoplasmatales archaea closely related to environmental phylotypes found in other ARD niches were also observed throughout the entire ecosystem. Overall, our study shows the differences and similarities in the diversity and distribution of the microbial communities between an ARD and a VARD system at the source and along the oxygen gradient that establishes on the course of the river.
\end{abstract}

Keywords Costa Rica $\cdot$ San Cayetano $\cdot$ Acid rock drainage $\cdot$ Microbial communities $\cdot$ Oxygen gradient

Electronic supplementary material The online version of this article (https://doi.org/10.1007/s00248-020-01530-9) contains supplementary material, which is available to authorized users.

Max Chavarría

max.chavarria@ucr.ac.cr

1 Microbial Interactions and Processes Research Group, Helmholtz Centre for Infection Research, 38124 Braunschweig, Germany

2 Present address: Department of Molecular Bacteriology, Helmholtz Centre for Infection Research, 38124 Braunschweig, Germany

3 Systems Biology Program, Centro Nacional de Biotecnología (CNB-CSIC), C/Darwin 3, 28049 Madrid, Spain

4 Centro Nacional de Innovaciones Biotecnológicas (CENIBiot), CeNAT-CONARE, San José 1174-1200, Costa Rica

5 Escuela de Química, Universidad de Costa Rica, San José 11501-2060, Costa Rica
6 Escuela Centroamericana de Geología, Universidad de Costa Rica, San José 11501-2060, Costa Rica

7 Laboratorio de Ecología Urbana, Universidad Estatal a Distancia, San José 11501-2060, Costa Rica

8 Escuela de Biología, Universidad de Costa Rica, San José 11501-2060, Costa Rica

9 Observatorio Vulcanológico y Sismológico de Costa Rica, Universidad Nacional (OVSICORI-UNA), Heredia 2386-3000, Costa Rica

10 Centro de Investigaciones en Productos Naturales (CIPRONA), Universidad de Costa Rica, Sede Central, San Pedro de Montes de Oca, San José 11501-2060, Costa Rica 


\section{Introduction}

The study of acid rock drainage (ARD) sites has provided a wealth of information about microbial populations adapted to extreme acidic environments. Most of the known ARD ecosystems in the world have been caused by human activity, especially mining processes [1-5]. ARD environments resulting from the exposure of metallic sulfide ores to the atmosphere due to mining activities are referred to as acid mine drainage (AMD) sites, while the term ARD is usually reserved for systems that are naturally originated. The anthropogenic influence modifies the geology, hydrology, and biology of the AMD, making it difficult to pinpoint the inherent geochemical and natural microbiological conditions of these sites. It is therefore interesting from an ecological and evolutionary point of view to study ARD ecosystems without anthropogenic influence. Unfortunately, there are far less studies on the geochemistry and microbiology of pristine natural ARD systems, for example, the Pastoruri Glacier area in Huascarán National Park (Perú) [6], the Antarctic landmass [7], and the Tinto river (in Spanish Río Tinto), located at the Iberian Pyrite Belt (IPB) of Spain [8-11]. In the latter case, although the river and its source are located on a site that has been mined for thousands of years $[12,13]$, it has been proposed that the conditions of extreme acidity and heavy metal pollution along the river are due to natural processes that were operative before mining activities began $[12,13]$. With the notable exception of the Tinto river, access to such remote locations hampers their study.

Besides these natural ARD sites, which are clearly associated with the oxidation of sulfide minerals (mostly pyrite), there are terrestrial acidic waters associated with hydrothermal springs or volcanic activity where $\mathrm{H}_{2} \mathrm{~S}$ oxidation or $\mathrm{SO}_{2}$ reaction with water produce sulfuric acid and whose geochemistry resemble ARD or AMD sites. These ARD-like environments share most of their natural composition (low $\mathrm{pH}$, high sulfate, and presence of metals such as iron) with that of ARD sites and are of interest because they can be unequivocally assigned to natural causes $[14$, 15]. In order to differentiate these locations from the ARD sites, we refer to these sites as volcanic acid rock drainage (VARD) environments. In a VARD hydrothermal or volcanic system, sulfuric acid promotes the dissolution of rock minerals generating water bodies with high content of metals, low $\mathrm{pH}$, and high sulfate levels comparable with ARD sites produced by pyrite oxidation. However, it is clear that the main geochemical processes that occur in ARD and VARD environments are different: while in ARD environments, acidity and high levels of iron are produced by oxidation of pyrite, whereas in VARD systems, acidity is produced by $\mathrm{H}_{2} \mathrm{~S}$ oxidation and $\mathrm{SO}_{2}$ water reaction, and high levels of iron (and other metals) are produced by the associated rock dissolution.
Natural ARD environments are characterized by the presence of iron- and sulfur-oxidizing bacteria. For example, in the natural ARD formed in the Pastoruri Glacier area, the presence of Acidithiobacillus, a sulfur- and iron-oxidizing acidophilic bacteria, was detected [6]. Dold et al. [7] reported the formation of an ARD system in the Antarctic landmass due to the activity of psychrophilic acid mine drainage microorganisms found in cold climates, specifically Acidithiobacillus ferrivorans, and Thiobacillus plumbophilus. Similarly, studies of ARD-like environments at Yellowstone National Park [16] and active volcanoes like Copahue in the Andes [15] have shown many parallels to ARD sites where iron- and sulfuroxidizing microorganisms also predominated.

The iron cycle is one of the most important biochemical processes that take place in these environments where microorganisms in oxic niches can oxidize ferrous iron with oxygen to generate metabolic energy. Microorganisms can also reduce ferric iron (or its minerals) to ferrous iron using organic matter [17]. At the origin of ARD's like the Tinto river, dominant organisms such as Acidithiobacillus and Leptospirillum act as primary producers obtaining energy from aerobic $\mathrm{Fe}(\mathrm{II})$ oxidation to $\mathrm{Fe}(\mathrm{III})$ complex oxides [10]. However, once anaerobic conditions are established in the sediments (or in deep, unmixed water), those same oxides can be used as electron acceptors for reduced organic matter or other electron sources by Acidiphilium, Acidimicrobium, Ferrimicrobium, and Ferroplasma [10], completing the iron cycle.

Being part of the Pacific Ring of Fire, Costa Rica's volcanoes have plenty of acidic volcanic lakes and rivers amenable for study [18]. In the country, multiple extreme environments with different physicochemical characteristics can be found, which fortunately do not have anthropogenic influence $[4,14$, 18]. Our group's first incursion into these local ARD-like sites was the study of the mineral-laden Sucio river (in Spanish Río Sucio due to abundant yellowish schwertmannite precipitation). Here, we found a striking abundance of Gallionella (44\%) and Ferrovaceae (33\%) species [14]. Our result compares well with studies in the Tinto river where $80 \%$ of the water column's bacterial species corresponds to only three bacterial genera: Leptospirillum, Acidithiobacillus, and Acidiphilium, all involved in iron-cycling [8, 19]. Minor levels of other iron-oxidizing bacteria such as Ferrimicrobium, Acidimicrobium, and Ferroplasma have also been detected in the Tinto river $[8,19]$.

In addition to the Sucio river, there are several yet unexplored extreme environments in the central volcanic mountain range of Costa Rica that we hypothesize correspond to natural ARD-like sites. Their study will increase our knowledge of microbial diversity and geochemical processes in these systems. In this particular study, we investigated the geochemical composition as well as the microbial community structure (bacteria and archaea) of a Costa Rican pristine VARD riverine environment known as San Cayetano. Based on the analysis of 16S rRNA gene 
amplicons, our results indicate that San Cayetano creek is both the result of volcanic input and biological activity of iron- and sulfur-oxidizing microorganisms distributed along an oxygen gradient. The similarities and differences of these less explored environments with respect to the typical ARD systems are discussed.

\section{Materials and Methods}

\section{Study Site}

The San Cayetano creek is located in a private farm northeast of the Irazu Volcano (Cartago, Costa Rica; Figs. 1 and 2; Suppl. Video 1). Due to its location within a private property and restricted access (the farm is already listed on the Costa Rican topo maps from the 1960s), this site has seen little human influence quite unlike other thermals in Costa Rica, which have been heavily visited since the tourism explosion in the 1990s. As shown in Fig. 2 and Suppl. Video 1, San Cayetano has its origin in a rocky outcrop within the forest where warm underground water emerges. From there, the creek flows for about $3 \mathrm{~km}$ to its confluence with the Sucio river [14]. Near the origin (SC-1 and SC-2), very clear water with a depth of about $1.3 \mathrm{~m}$ flows smoothly over a clean gravel riverbed, but due to the mountainous relief of the area, $20 \mathrm{~m}$ downstream the water goes through a 6-m waterfall where a light-brown microbial mat is formed. From this point on, water flows faster (SC-3 to SC-5) and it is estimated to discharge at a rate of about $100 \mathrm{~L} / \mathrm{s}$ (Baldoni et al. unpublished). Permits for sampling were obtained from the Institutional Commission of Biodiversity of the University of Costa Rica (resolution no. 066) and the owners of the property.
Fig. 1 San Cayetano stream in Central Mountain Range, Costa Rica. San Cayetano is located in the Central Volcanic Range, about $5 \mathrm{~km}$ North of Irazu Volcano's Crater. The stream has a length of about $3 \mathrm{~km}$ until its junction with the Sucio river. At the map's scale sampling points SC-1, SC-2, and SC-3 are very close to one another and are indicated by a single dot. SC-1 is the actual hypoxic river source. Between SC-2 and SC-3, there is a small waterfall where water first becomes oxygenated

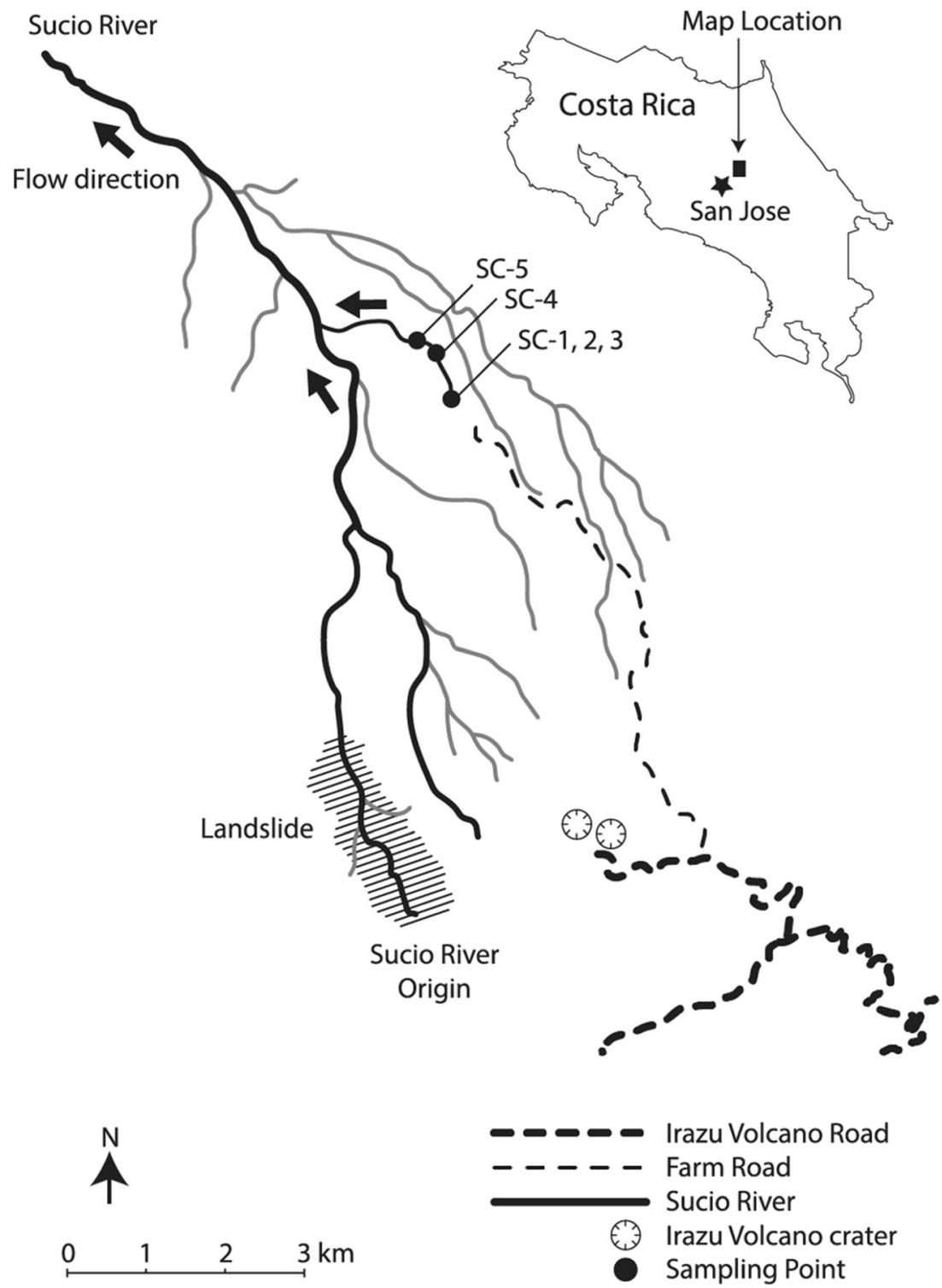




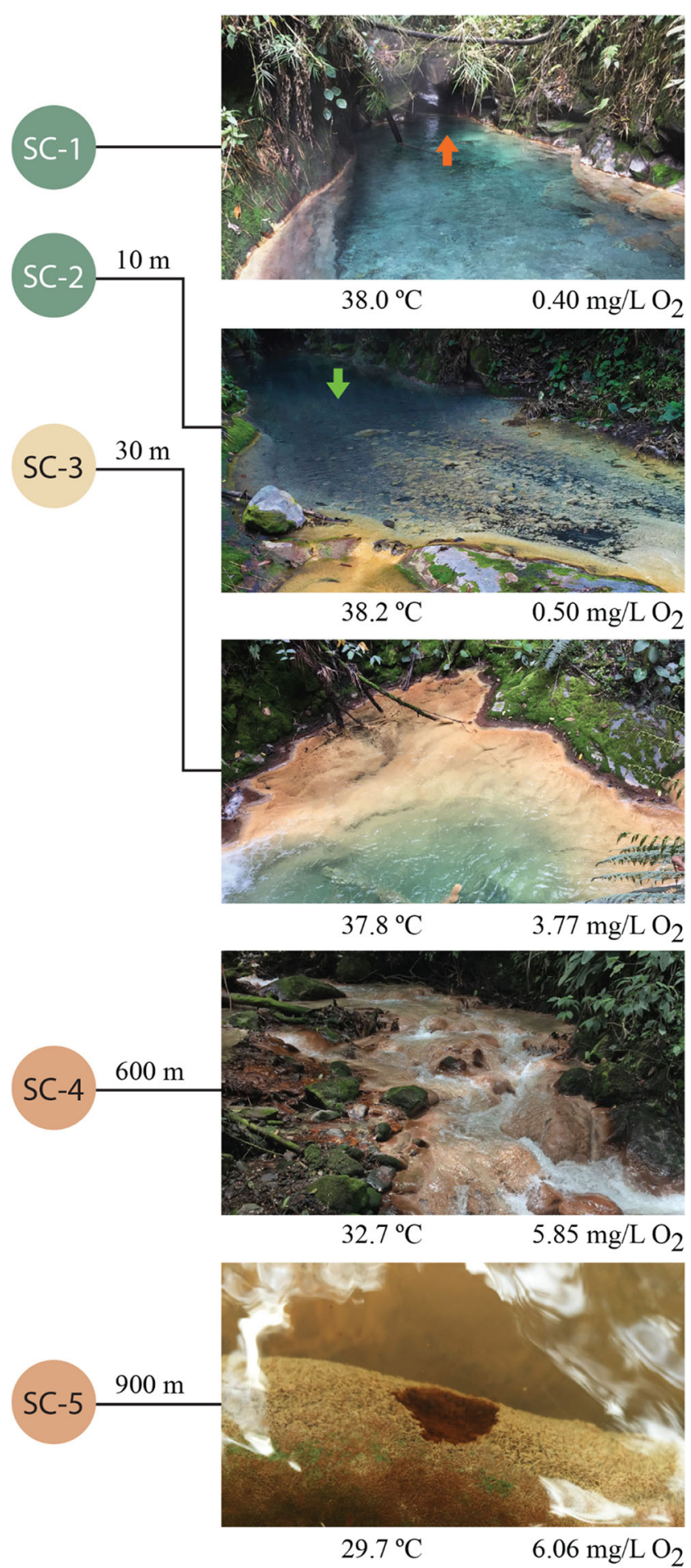

Fig. 2 Sampling points along San Cayetano stream. The distance from the source $\mathrm{SC}-1$ is shown on the left, with temperature and oxygen content underneath each photograph. SC-1 is a view of the hypoxic river source (marked by the red arrow) and the slow-moving hypoxic water that flows towards the right. The second image SC-2 shows the pool as seen from the top of the waterfall (the sampling site at the pool is marked here by a green arrow). SC-3 is the oxic bottom of the waterfall that lies between SC-2 and SC-3 as seen from its top. Notice that a beige-colored mat begins to form. SC-4 represents the typical aspect of the oxic creek with beige sediment on the rocks. A close-up view of the organic mat at SC-5 shows underwater mosses and red sediment underneath

\section{Sampling and Field Measurements}

In August 2016, water samples were collected at five different points chosen according to their water flow characteristics and accessibility along the stream. At each point, three samples of water $(1 \mathrm{~L}$ each) were collected (i.e., 15 total water samples; see Fig. 2): SC-1 (sampling point located at the origin, $10.032308 \mathrm{~N}$ 83.864449 W), SC-2 (10 m away from the origin in a slow flowing pond), SC-3 (30 m away from the origin at the base of the first waterfall), SC-4 (600 m away from the origin), and SC-5 (900 $\mathrm{m}$ away from the origin). For sediment sampling, masses between 10 and $50 \mathrm{~g}$ were placed into sterile $50-\mathrm{mL}$ centrifuge tubes. The sediments were taken at depths not exceeding $15 \mathrm{~cm}$. Because some areas were completely or mostly rocky, the amount of sediment taken varies between each sampling point. Thus, rocky SC-1 yielded no sediment for collection, yet sediment samples were obtained from the second (SC-2S1, SC-2S2, SC-2S3), third (SC-3S1, SC-3S2, SC-3S3), fourth (SC-4S1), and fifth sampling points (SC-5S1, SC-5S2, SC-5S3, SC-5S4) for a total of 11 sediment samples. In the field, the temperature and dissolved oxygen (DO) were measured in water samples with a dissolved oxygen meter Model 550A (Yellow Springs Instrument Company Inc., OH, USA). pH was measured with a $\mathrm{pH}$ meter (Scholar 425 pH meter, Corning, Inc., Corning, NY) in the laboratory. Water samples for chemical analysis were collected in clean glass bottles, chilled on ice, and stored at $4{ }^{\circ} \mathrm{C}$ until analysis. Water samples for microbial community analysis were collected in clean and sterile bottles and processed within less than $24 \mathrm{~h}$.

\section{Geochemical Analysis}

For chemical analysis, water samples were filtered with polycarbonate membrane filters $(0.45 \mu \mathrm{m}$; Sartorius $23006-47 \mathrm{~N})$ before analysis. The sediments ( $0.2-0.3 \mathrm{~g}$ of each) were subjected to acid digestion with a mixture of hydrochloric acid, nitric acid, hydrofluoric acid, and boron in a MARS 6 microwave system (CEM Corp., USA) using the application for rocks and cement. After digestion, the sample was diluted to $100.00 \mathrm{~mL}$ and filtered with polycarbonate membrane filters $(0.45 \mu \mathrm{m}$; Sartorius $23006-47 \mathrm{~N})$ before analysis by ICP-MS. Major anionic components $\left(\mathrm{Cl}^{-}, \mathrm{F}^{-}, \mathrm{NO}_{3}{ }^{-}, \mathrm{SO}_{4}{ }^{-2}\right)$ in the water samples were analyzed by ion-exchange chromatography (IC, MIC-II, Metrohm Co., Switzerland) using an anionic exchange resin (Metrosep A Supp 5 - 100/4.0). Operating conditions were a mobile phase at $33{ }^{\circ} \mathrm{C}, \mathrm{Na}_{2} \mathrm{CO}_{3}(3.2 \mathrm{mM}) /$ $\mathrm{NaHCO}_{3}(1.0 \mathrm{mM})$, and flow rate $0.7 \mathrm{~mL} / \mathrm{min}$. The anions were identified and quantified relative to certified commercial standards (Certipur ®Anion multi-element standard I, II, Merck, Germany). On the other hand, elemental components (Al, As, Cd, Ca, Cu, Cr, Fe, Mg, Mn, Ni, Pb, K, Na) were analyzed by inductively coupled plasma mass spectrometry (ICP-MS, Agilent 7500 instrument, Agilent Technologies, Tokyo, Japan) using a certified multi-element stock solution 
(Perkin-Elmer Pure Plus standard, product number 9300233). All determinations were made with three independent samples and the reported results correspond to their average. The uncertainty $( \pm$ ) was calculated using the standard deviation (s) of the three repetitions $(n=3)$ with a coverage factor $K=2$.

\section{Total DNA Isolation, Construction of 16S rRNA Gene Libraries and Illumina Sequencing}

The three water samples from each sampling point $(3 \times 1 \mathrm{~L}$ each) were pooled and filtered through a vacuum system under sterile conditions using a membrane filter (pore size $0.22 \mu \mathrm{m}$; Millipore, GV CAT No GVWP04700). To prevent rupture, another filter membrane (pore size $0.45 \mu \mathrm{m}$; Phenex, Nylon Part No AF0-0504) was placed below. The upper filter was collected and stored at $-80{ }^{\circ} \mathrm{C}$ until processing. DNA extraction was performed on the entire filter. For this, the filter was cut into pieces aseptically, the pieces separated into groups, and each group individually extracted with a DNA isolation kit (PowerSoil®, MoBio, Carlsbad, CA, USA) as described by the manufacturer. DNA extracted from all filter pieces was pooled for the following stages. To process the sediments, a representative sample of $500 \mathrm{mg}$ (obtained by homogenization with vortex and then through grid sampling) was collected from 10 to $50 \mathrm{~g}$ of each wet sediment (i.e., from the 11 samples) and DNA extracted using the same protocol. Cell lysis was accomplished by two steps of bead beating (FastPrep-24, MP Biomedicals, Santa Ana, CA, USA) for $30 \mathrm{~s}$ at $5.5 \mathrm{~m} \mathrm{~s}^{-1}$. For the construction of microbial $16 \mathrm{~S}$ rRNA amplicon libraries, the V5-V6 hypervariable regions were PCR-amplified with universal primers 807F (5'-GGAT TAGATACCCBRGTAGTC-3') and 1050R (5'AGYTGDCGACRRCCRTGCA-3') [20]. The barcoding of the DNA amplicons and the addition of Illumina adaptors were conducted by PCR from approximately $1-10 \mathrm{ng}$ of total DNA as described previously [21]. The PCR-amplified amplicons were verified by $1 \%$ agarose gel electrophoresis, purified using the QIAquick Gel Extraction Kit (Qiagen, Hilden, Germany), and quantified with the Quant-iT PicoGreen dsDNA reagent kit (Invitrogen, Darmstadt, Germany). The individual amplicons were pooled to equimolar ratios (200 ng of each sample) and purified with the QIAquick PCR Purification Kit (Qiagen, Hilden, Germany). Finally, PCR-generated amplicon libraries were subjected to 250-nt paired-end sequencing on a MiSeq platform (Illumina, San Diego, CA, USA).

\section{Bioinformatic and Phylogenetic Analysis of 16S rDNA Amplicon Data}

The sequence data were deposited in the sequence-read archive (SRA) of GenBank under the BioProject ID PRJNA616297. Bioinformatic processing was performed as previously described
[22]. Raw reads were merged with the Ribosomal Database Project (RDP) assembler [23], obtaining overall 530,413 paired-end reads. Sequences were aligned within MOTHUR (Gotoh algorithm using the SILVA reference database; [24]) and subjected to preclustering ( $($ iffs $=2$ ) yielding the so-called operational taxonomic units (OTUs) or phylotypes that were filtered for an average abundance of $\geq 0.001 \%$ and a sequence length $\geq 250$ bp before analysis. OTUs were taxonomically classified into the SILVA v132 taxonomy [25] as reported by the SINA classification tool [26]. OTUs were assigned to a taxonomic rank only if their best hit in the SILVA database [27] had an identity higher than the threshold established by Yarza et al. [28] for that rank $(94.5 \%$ for genus, $86.5 \%$ for family, $82.0 \%$ for order, $78.5 \%$ for class, and $75.0 \%$ for phylum). Moreover, the sequences of some highly abundant OTUs were also manually examined by means of BLASTN [29] against the non-redundant and against the bacterial and archaeal $16 \mathrm{~S}$ rRNA databases. The statistical analyses and visualizations were performed in $\mathrm{R}$ [30]. We used Vegan [31] to calculate alpha diversity estimators, nonmetric multidimensional scaling analyses, (NMDS). Data tables with the OTU abundances per sample were normalized into relative abundances and then converted into a Bray-Curtis similarity matrix. The effects of the environmental factors on the bacterial community composition were evaluated with non-parametric multivariate analysis of variance (PERMANOVA) and pairwise PERMANOVA (adonis function in package Vegan with 999 permutations). The homogeneity of group dispersions was also checked for the factors analyzed with the betadisper and (pairwise) permutest function.

\section{Results and Discussion}

\section{Physicochemical Analysis of San Cayetano Stream}

Stream water in the $0.9-\mathrm{km}$ section of the San Cayetano rock drainage system (Fig. 1) had a constant $\mathrm{pH}$ of $3.0 \pm 0.1$ (Table 1) and temperatures of $\sim 38^{\circ} \mathrm{C}$ at $\mathrm{SC}-1$ (source) to $~$ $30{ }^{\circ} \mathrm{C}$ in SC-5 (Fig. 2). A prominent gradient in the oxygen concentration was observed throughout San Cayetano creek: in $\mathrm{SC}-1$, conditions were hypoxic $\left(0.40 \mathrm{mg} \mathrm{L^{-1 }} \mathrm{O}_{2}\right.$ corresponding to an oxygen saturation of $6.6 \%$ at the temperature and pressure of the sampling site), while at the last sampling point, SC-5 water had become oxic $\left(6.06 \mathrm{mg} \mathrm{L}^{-1} \mathrm{O}_{2} ; 81 \% \mathrm{O}_{2}\right.$ saturation). In points SC-4 and SC-5, the creek has already flowed more than $600 \mathrm{~m}$ and through air contact has increased its dissolved oxygen content. Water turbulence and waterfalls like the one existing after point SC-2 are responsible for a fairly oxic stream.

Water samples (Table 1$)$ contained sulfate $(\sim 0.87-$ $\left.1.19 \mathrm{~g} \mathrm{~L}^{-1}\right)$, total iron $\left(\sim 35-61 \mathrm{mg} \mathrm{L}^{-1}\right.$; ferrous and ferric iron species were not measured separately), manganese $(\sim 1.98$ $\left.2.05 \mathrm{mg} \mathrm{L}^{-1}\right)$, aluminum $\left(\sim 33-45 \mathrm{mg} \mathrm{L}^{-1}\right)$, chromium $(\sim 29$ 
Table 1 Physical properties and geochemical composition of San Cayetano waters. SC-1 corresponds to pore water (the origin) while samples SC-2 to SC-5 correspond to surface water. Major anionic components were analyzed by IC and elemental components by ICP-MS

\begin{tabular}{lccccc}
\hline property and element/ion & $\mathrm{SC}-1$ & $\mathrm{SC}-2$ & $\mathrm{SC}-3$ & $\mathrm{SC}-4$ & $\mathrm{SC}-5$ \\
\hline Temperature $\left({ }^{\circ} \mathrm{C}\right) / \pm 0.1$ & 38.0 & 38.2 & 37.8 & 32.7 & 29.7 \\
$\mathrm{pH} / \pm 0.1$ & 3.0 & 2.9 & 3.0 & 3.1 & 3.0 \\
Dissolved oxygen $\left(\mathrm{mg} \mathrm{L}^{-1}\right) / \pm 0.01$ & 0.40 & 0.50 & 3.77 & 5.85 & 6.06 \\
Aluminum $\left(\mathrm{mg} \mathrm{L}^{-1}\right) \pm 5$ & 41 & 33 & 41 & 34 & 45 \\
Arsenic $\left(\mu \mathrm{g} \mathrm{L}^{-1}\right) \pm 0.7$ & 19.2 & 20.8 & 20.7 & 12.9 & 11.3 \\
Cadmium $\left(\mu \mathrm{g} \mathrm{L}^{-1}\right)$ & $<0.11$ & $<0.11$ & $<0.11$ & $<0.11$ & $<0.11$ \\
Calcium $\left(\mathrm{mg} \mathrm{L}^{-1}\right) \pm 2$ & 4 & 4 & 4 & 4 & 3 \\
Chloride $\left(\mathrm{mg} \mathrm{L}^{-1}\right) \pm 10$ & 246 & 203 & 227 & 200 & 222 \\
Copper $\left(\mathrm{mg} \mathrm{L}^{-1}\right)$ & $<0.10$ & $<0.10$ & $<0.10$ & $<0.10$ & $<0.10$ \\
Chromium $\left(\mu \mathrm{g} \mathrm{L}^{-1}\right) / \pm 2$ & 30 & 33 & 33 & 32 & 29 \\
Fluoride $\left(\mathrm{mg} \mathrm{L}^{-1}\right)$ & $<0.09$ & $<0.09$ & $<0.09$ & $<0.09$ & $<0.09$ \\
Total iron* $\left(\mathrm{mg} \mathrm{L}^{-1}\right) / \pm 2$ & 45 & 51 & 61 & 40 & 35 \\
Magnesium $\left(\mathrm{mg} \mathrm{L}^{-1}\right) \pm 3$ & 58 & 64 & 64 & 63 & 59 \\
Manganese $\left(\mathrm{mg} \mathrm{L}^{-1}\right) \pm 0.06$ & 1.98 & 2.05 & 1.98 & 2.00 & 2.02 \\
Nickel $\left(\mu \mathrm{g} \mathrm{L}^{-1}\right) / \pm 2$ & 6 & 10 & 8 & 10 & 10 \\
Nitrate $\left(\mathrm{mg} \mathrm{L}^{-1}\right)$ & $<0.10$ & $<0.10$ & $<0.10$ & $<0.10$ & $<0.10$ \\
Lead $\left.(\mu \mathrm{g} \mathrm{L})^{-1}\right)$ & $<1.2$ & $<1.2$ & $<1.2$ & $<1.2$ & $<1.2$ \\
Potassium $\left(\mathrm{mg} \mathrm{L}^{-1}\right) \pm 0.6$ & 31.8 & 34.2 & 33.4 & 35.0 & 33.8 \\
Sodium $\left(\mathrm{mg} \mathrm{L}^{-1}\right) \pm 2$ & 73 & 79 & 78 & 78 & 75 \\
Sulfate $\left(\mathrm{mg} \mathrm{L}^{-1}\right) \pm 50$ & 1190 & 950 & 883 & 870 & 874 \\
Zinc $\left(\mu \mathrm{g} \mathrm{L}{ }^{-1}\right) \pm 10$ & 115 & 109 & 141 & 119 & 121 \\
\hline & & & & & \\
\hline
\end{tabular}

*The data correspond to total iron. Iron speciation was not measured $\left.33 \mu \mathrm{g} \mathrm{L}^{-1}\right)$, zinc $\left(\sim 109-121 \mu \mathrm{g} \mathrm{L}^{-1}\right)$, arsenic $(\sim 11.3-$ $\left.20.8 \mu \mathrm{g} \mathrm{L}^{-1}\right)$, and magnesium $\left(\sim 58-64 \mathrm{mg} \mathrm{L}^{-1}\right)$. Most of these concentrations are much higher than those of freshwater rivers used for human activities in Costa Rica [32] but are comparable with the amounts found in ARD environments [4]. As expected, sediment samples also contain significant amounts of several metals measured in high concentrations in water samples (see above, according to reference [32]) like manganese (8-49 $\left.\mathrm{mg} \mathrm{kg}^{-1}\right)$, aluminum $\left(1.6-4.6 \mathrm{~g} \mathrm{~kg}^{-1}\right)$, chromium (21-74 $\left.\mathrm{mg} \mathrm{kg}^{-1}\right)$, and zinc (9-14 $\mathrm{mg} \mathrm{kg}^{-1}$ ) (Table 2). Notably, sediment samples showed a significant increase in iron content (8-293 $\left.\mathrm{mg} \mathrm{kg}^{-1}\right)$ as the river flows downstream (Table 2). Accordingly, SC-2S sediments ( $10 \mathrm{~m}$ far away from the origin) had much less iron $\left(8 \pm 1 \mathrm{mg} \mathrm{kg}^{-1}\right)$ than sediments in SC-3S (30 m far away from the origin; $195 \pm 35 \mathrm{mg} \mathrm{kg}^{-1}$ ), SC-4S (600 m far away from the origin; $220 \pm 32 \mathrm{mg} \mathrm{kg}^{-1}$ ),

Table 2 Elemental composition of San Cayetano sediments. Data are not included for the first sampling site (i.e., SC-1) because being a rocky area, it was not possible to collect sediments. Elemental components were analyzed by ICP-MS

\begin{tabular}{|c|c|c|c|c|}
\hline Element & SC-2S & SC-3S & SC-4S & SC-5S \\
\hline Aluminum $\left(\mathrm{g} \mathrm{kg}^{-1}\right)$ & $4.6 \pm 1.2$ & $2.0 \pm 0.4$ & $3.0 \pm 0.6$ & $1.6 \pm 0.6$ \\
\hline Cadmium $\left(\mu \mathrm{g} \mathrm{kg}^{-1}\right)$ & $42 \pm 12$ & $19 \pm 1$ & $36 \pm 4$ & $13 \pm 3$ \\
\hline Copper $\left(\mathrm{mg} \mathrm{kg}^{-1}\right)$ & $12 \pm 2$ & $5.2 \pm 0.6$ & $7.4 \pm 0.9$ & $3.3 \pm 0.7$ \\
\hline Chromium (mg kg ${ }^{-1}$ ) & $21 \pm 5$ & $45 \pm 4$ & $74 \pm 9$ & $50 \pm 9$ \\
\hline Total iron* $\left(\mathrm{g} \mathrm{kg}^{-1}\right)$ & $8 \pm 1$ & $195 \pm 35$ & $220 \pm 32$ & $293 \pm 49$ \\
\hline Manganese $\left(\mathrm{mg} \mathrm{kg}^{-1}\right)$ & $49 \pm 8$ & $13 \pm 1$ & $26 \pm 3$ & $8 \pm 2$ \\
\hline Nickel (mg kg $\left.{ }^{-1}\right)$ & $29 \pm 5$ & $5.5 \pm 0.2$ & $13 \pm 2$ & $2.2 \pm 0.5$ \\
\hline Lead $\left(\mathrm{mg} \mathrm{kg}^{-1}\right)$ & $2.2 \pm 0.6$ & $0.79 \pm 0.02$ & $1.9 \pm 0.2$ & $0.45 \pm 0.09$ \\
\hline Zinc $\left(\mathrm{mg} \mathrm{kg}^{-1}\right)$ & $14 \pm 2$ & $8.5 \pm 0.7$ & $13 \pm 1$ & $11 \pm 2$ \\
\hline
\end{tabular}

*The data correspond to total iron. Iron speciation was not measured 
and SC-5 (900 $\mathrm{m}$ far away from the origin; $293 \pm 49 \mathrm{mg} \mathrm{kg}^{-1}$ ). As the river progresses, we then observe a steady increase in iron precipitation.

The low [total iron]/[sulfate] ratio and the absence of visible precipitated iron minerals (see Fig. 2a, b), as it occurs in Sucio river with the iron-oxyhydroxysulfate schwertmannite [14], suggest that much of the sulfate is produced from volcanic sources (i.e., from biotic and/or abiotic $\mathrm{H}_{2} \mathrm{~S}$ oxidation and $\mathrm{SO}_{2}$ water reaction) rather than being the result of oxidation of pyrites or other metal sulfides. For example, in the Tinto river ARD system, the $\left[\mathrm{Fe}_{\mathrm{Total}}\right] /\left[\mathrm{SO}_{4}{ }^{-2}\right]$ molar ratio is 0.58 at the origin and only decreases to 0.29 downstream [10] as expected from the 0.5 ratio from the oxidation of pyrite $\mathrm{FeS}_{2}(1: 2 \mathrm{M}$ ratio Fe:S, i.e. 0.5). However, in the San Cayetano stream, we measure much lower ratios as small as 0.07 at the origin and 0.07-0.12 downstream. These ratios are similar to those observed at Copahue's river sites (ratios 0.15-0.06) [15]. The moderately-high water temperature $\left(\sim 38^{\circ} \mathrm{C}\right)$ at the origin of San Cayetano also indicates hydrothermal influence. These observations suggest that the extreme conditions observed in San Cayetano are likely due to the discharge products of volcanic or hydrothermal activity into the water bodies of the river, a feature well described in geology [33]. Thus, considering our data and the geological information of the IrazuTurrialba volcanic complex [34-38], it is reasonable to propose that the acidic aquifer at San Cayetano (as well as other acidic hot springs in the northern flank of Irazu Volcano) results from the interaction of meteoric water from the aquifer and the magmatic system. Magma degassing usually produces $\mathrm{SO}_{2}, \mathrm{HCl}$, and $\mathrm{HF}$ gases that hydrolyze generating highly acidic hydrothermal-magmatic fluids. Large amounts of sulfuric acid are produced by the high-temperature disproportionation reaction $3 \mathrm{SO}_{2}+2 \mathrm{H}_{2} \mathrm{O} \rightarrow 2 \mathrm{H}_{2} \mathrm{SO}_{4}+\mathrm{S}$ [33] which acidifies the hydrothermal water and dissolves the andesite rocks that have been reported as the most common in the area [34-38] partially neutralizing the acid to $\mathrm{pH} \sim 3[39,40]$. We do not expect sulfur deposits because it is something that occurs near the magma chamber. Sulfur, which is insoluble, stays in the volcano and gaseous $\mathrm{SO}_{2}$ mixes with water. Rock dissolution contributes with iron, manganese, aluminum, and other rock-forming elements to the water, which is consistent with our results (Tables 1 and 2). Other acid sources like biotic and/or abiotic $\mathrm{H}_{2} \mathrm{~S}$ oxidation could also be minor contributors to the acidity of infiltration on the volcanic slope. San Cayetano resembles ARD sites, with the important difference that its acidity and metallic content is produced abiotically rather than from microbe-mediated metal sulfide-rock dissolution (as occurring in Tinto river). Thus, as mentioned above, we refer to this kind of site like volcanic influenced acidic rock drainage (VARD) systems.

In summary, the physicochemical parameters of San Cayetano suggest that (i) the selected sampling points describe a gradient of increasing oxygen concentration starting at the origin with almost anoxic conditions (i.e., hypoxic, $0.40 \mathrm{mg}$ $\mathrm{O}_{2} \mathrm{~L}^{-1}$ corresponding to an oxygen saturation of $6.6 \%$ ), (ii) the iron content in the sediments increases as the river flows downstream (8-293 $\mathrm{mg} \mathrm{kg}^{-1}$ ), and (iii) San Cayetano has the typical chemical composition of an ARD environment but with an important contribution of sulfuric acid generated by volcanic processes whereby we define it as a volcanic influenced acid rock drainage (VARD) system.

\section{The Concentrations of Dissolved Oxygen Along the River Shape the Microbial Community of San Cayetano}

In spite of the acidic conditions and high concentrations of sulfate, iron, and toxic metals, we identified 1904 OTUs in this ecosystem from 530,310 16S rRNA gene sequences (excluding singletons). These OTUs were assigned to 36 phyla and 177 families from both bacteria and archaea (Fig. 3 and Supplementary Table 1). The most abundant phylogenetic groups of bacteria were Gammaproteobacteria (40.2\%), Actinobacteria (9.1\%), Nitrospirae $(6.4 \%)$, and Firmicutes (6.2\%) while the most abundant phylogenetic group of archaea was Euryarchaeota (10.0\%). However, we detected important differences in the microbial community composition between the different sampling sites (Fig. 3). We also observed that 63\% of the samples presented richness values greater than 500 OTUs and that $88 \%$ of the samples presented values of the Shannon index greater than 3 (Supplementary Figure S1).

The taxonomic composition of San Cayetano had a remarkable relative abundance (4.1-14.6\%) of unclassified microorganisms in the water and sediment samples, especially in the water taken at the first two sampling points that had low dissolved oxygen concentrations $\left(<0.50 \mathrm{mg} \mathrm{L}^{-1}\right)$. Nevertheless, we could detect the presence of microorganisms commonly found in ARD environments like iron-, sulfur-, sulfide-, and thiosulfate-oxidizing bacteria. The physicochemical analysis of waters revealed that oxygen was the chemical species that showed the greatest changes during the course of the river. Thus, we resolved to apply non-parametrical analyses of the microbial composition based on the oxygen content. The PERMANOVA results showed significant differences in the community structure at the OTU level (PERMANOVA, $P=0.001$ ) along the oxygen gradient. The NMDS analyses also indicate a prominent role of oxygen in shaping the structure of the microbial communities in the VARD ecosystem (Fig. 4). We observed a clear separation of the samples according to the oxygen content. The difference between microbial communities in the water column compared with those in sediments was also significant (PERMANOVA, $P=0.018$ ). The water samples near the origin (SC-1 and SC-2) that contain very little concentrations of oxygen showed very similar microbial communities. They were, however, clearly distinct from the communities in the respective sediments (SC-2S1, 


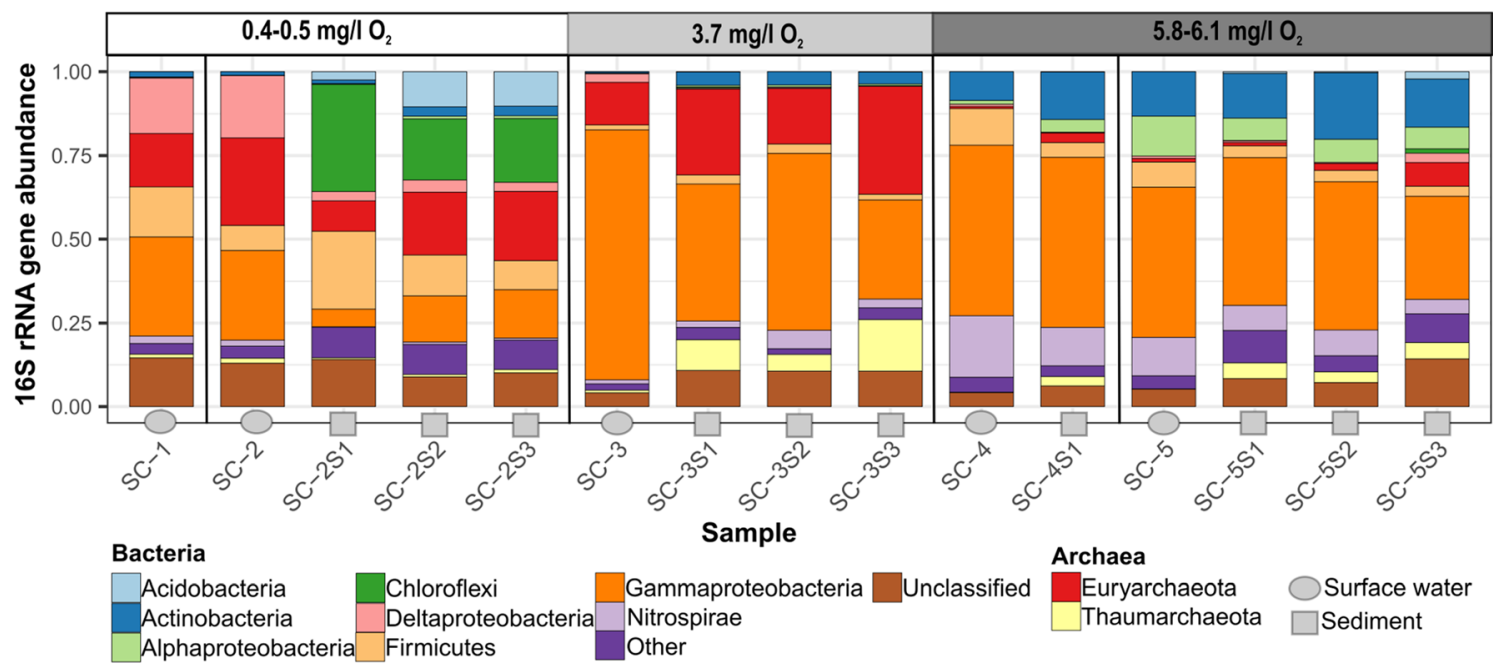

Fig. 3 Taxonomic composition of San Cayetano. Relative abundance of bacterial and archaeal 16S rRNA sequences shown at the phylum level. The OTUs were classified according to the Silva v132 database using the SINA classification tool. A number of unclassified microorganisms are

SC-2S2, and SC-2S3). As expected, samples from the third sampling point (containing intermediate levels of oxygen) did not group with SC-1 and SC-2 (low oxygen) nor with SC-4 and $\mathrm{SC}-5$ (high oxygen). Whereas the respective sediment communities were similar (SC-3S1, SC-3S2, and SC-3S3), they were distinct from water samples from the same sampling spot (SC-3). Finally, the water samples of points four and five, as well as their sediments, clustered together. The last two included. The category "other" represents 27 phyla with lower abundances. Oxygen gradient is shown in the upper bar. Samples from sediments and the surface water are also marked

sampling points are characterized by very similar aerobic conditions, so it is expected that the microbial community in these sites is similar.

To detect the interactions between the concentration of metals in sediments and the structure of the microbial (both bacteria and archaea) communities (at OTU level), we performed a canonical correspondence analysis and used the envfit function of package Vegan to get the $P$ value of the
Fig. 4 Non-metric

multidimensional scaling analysis of the microbial communities in San Cayetano volcanic influenced acid rock drainage. A clustering of communities according to the oxygen content of the samples and also by the habitat (water column versus sediment) is shown. The NMDS and the PERMANOVA analyses $(P=$ $0.001)$ were performed with the package Vegan

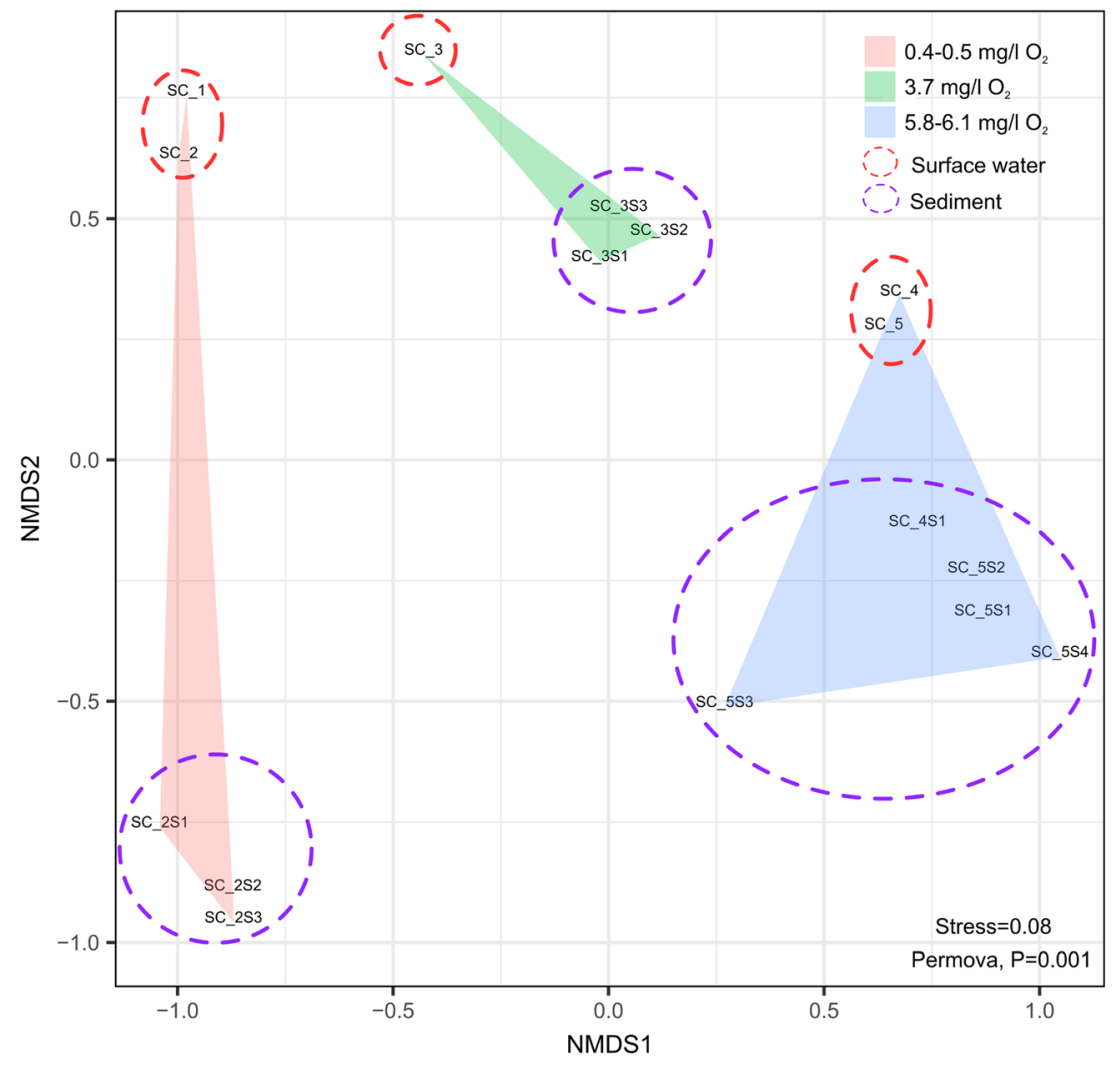


correlation of each variable with overall community structure. The results of this analysis are shown in Supplementary Figure S2 and are consistent with previous results showing significant differences in the composition of the communities along the river. As the flow progresses, there was more oxygen in the water column and a considerable increase of iron in the sediments, particularly in sediments of sites four and five. On the contrary, as the distance from the river's origin increased, we observed a reduction in the temperature of the water and in the concentration of manganese, nickel, lead, and copper in the sediments.

As mentioned above, at the first sampling point (SC-1), which corresponds to the source, it was not possible to obtain sediment samples and the water contained only $0.40 \mathrm{mg} \mathrm{L}^{-1}$ $\mathrm{O}_{2}$. The microbial community of the water sample (SC-1 in Fig. 5 and Supplementary Table 1) was dominated by an unclassified Deltaproteobacterium (OTU_SC0012; 14.8\% of the total reads i.e. relative abundance in SC-1), with the partial 16S rDNA sequence showing high $(97.2 \%)$ similarity to environmental OTUs obtained from other ARD environments such as Tinto river, Spain (NCBI accession FN862110), the Tongling acid mine drainage (NCBI accession KC749174), and the Dexing copper mine in China (NCBI accession EF409870). Interestingly, the 16S rDNA sequence of this Deltaproteobacterium was also similar $(96.8 \%)$ to that of the uncultured phylotype K5_62 (NCBI accession EF464599; Desulfovirga adipica strain TsuA1), which has been proposed to represent a novel type of acidophilic sulfate-reducing bacteria [41]. Given the high concentrations of sulfate in the origin of San Cayetano $\left(\sim 1.19 \mathrm{~g} \mathrm{~L}^{-1}\right)$, the presence of microorganisms capable of using this oxyanion as the terminal electron acceptor is expected.

The second most abundant microorganism in the origin of San Cayetano (OTU_SC0019; 14.5\%) corresponds to an unclassified bacterium. The $16 \mathrm{~S}$ rDNA sequence revealed that the first 183 nucleotides of the sequenced fragment share $96.7 \%$ of similarity with Sulfobacillus thermosulfidooxidans, while the rest of the sequence corresponds to a low complexity, GC-
Fig. 5 Heat map representing the most abundant genera of archaea and bacteria in each sample. The heat map depicts the relative percentage of 16S rRNA gene sequences assigned to each genus ( $y$ axis) across the 16 samples analyzed ( $x$ axis). Square colors shifted towards black indicate higher abundance. Samples from surface water and sediments are marked
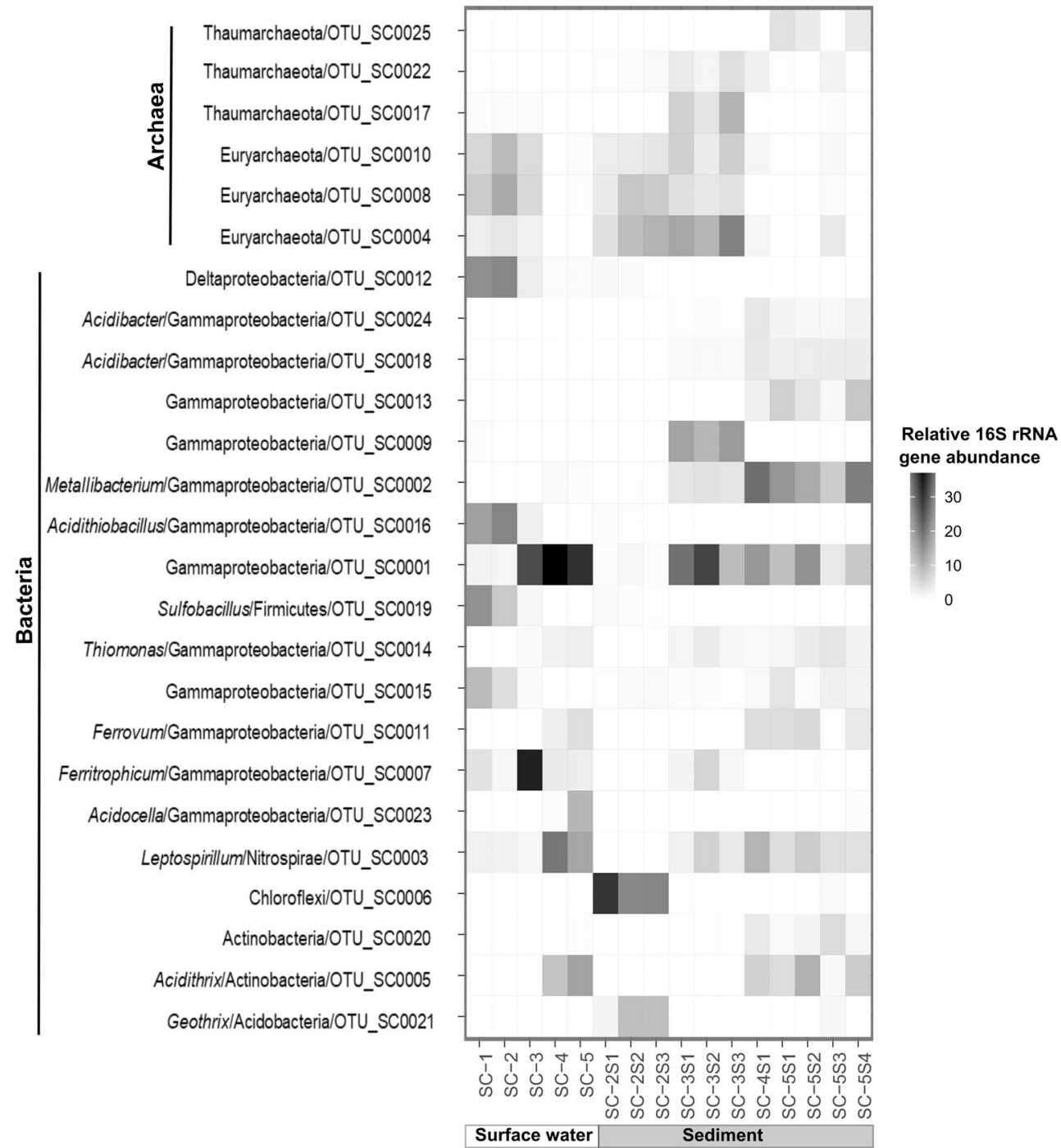
rich DNA region that does not match with any other sequence within the non-redundant nucleotide collection (Supplementary Table S1). We therefore manually curated the sequence of this OTU and we reassign it within genus Sulfobacillus (Fig. 5). These bacteria are Gram-positive, moderately thermophilic, facultative anaerobic [42] acidophiles that grow in sulfurous and sulfidic environments. It has been previously reported that they attach to sulfide mineral surfaces, which may promote faster sulfide oxidation [43]. Sulfobacillus species are also involved in ferrous iron oxidation [44, 45]. In addition to these two highly represented genera in the water samples of the origin of San Cayetano, we identified other microorganisms related to acidophilic, sulfur- and iron-oxidizing bacteria, such as Acidithiobacillus (OTU_SC0016; 12.5\%). This genus includes chemolithotrophic bacteria capable of oxidizing sulfide to sulfate, coupling this reaction to ferric iron (under anoxic conditions) or oxygen (under oxic conditions) reduction [46-48]. Together with Acidithiobacillus, another putative chemolithotrophic sulfur oxidizer from the family Hydrogenophilaceae was observed in high relative abundance in the water sample SC-1 (OTU_SC0015; 8.9\%). This organism is closely related to a group of bacteria capable to obtain energy by the oxidation of sulfur compounds with oxygen or nitrate as the terminal electron acceptor, including Sulfuritortus calidifontis (93.2\% of similarity according to BLAST), Annwoodia aquaesulis (92.8\% similarity), and Thiobacillus thioparus (92.4\% similarity) [49, 50].

Two archaea from the order Thermoplasmatales were detected among the most abundant microorganisms in the water samples from SC-1 (OTU_SC0008; 6.6\% and OTU_SC0010; $5.0 \%$ of total SC-1 reads). Both OTU phylotypes share high $16 \mathrm{~S}$ rDNA sequence similarity to environmental OTUs detected in other ARD niches such as the Tinto river (NCBI accession FN862291), the hydrothermal ponds in the Copahue region in Argentina (NCBI accession JX989254), or the Kamchatkan hot springs in Russia (NCBI accession JF317816). The closest isolates in both cases belong to the genus Cuniculiplasma (Fig. 5 and Supplementary Table 1). Archaea from the order Thermoplasmatales are considered acidophiles that generally grow at $\mathrm{pH}$ less than 4 [51]. Specifically, Cuniculiplasma is classified as facultative anaerobic, organotrophic, and mesophilic where the only isolate (C. divulgatum) was obtained from acidic streamers formed on the surfaces of copper-ore-containing sulfidic deposits in south-west Spain and North Wales, UK [52]. Other species of the order Thermoplasmatales such as Thermoplasma acidophilum [53], Thermoplasma volcanium [54], Thermogymnomonas acidicola [55], and Picrophilus torridus $[56,57]$ have been obtained from solfataric hydrothermal areas or acidic streamers containing sulfidic deposits, i.e., sulfur-rich environments. Thus, it is likely that the two Thermoplasmatales OTUs found at the spring waters of San Cayetano are also involved in sulfur metabolism.
At the second sampling point (SC-2), just $10 \mathrm{~m}$ from the origin, the content of dissolved oxygen increases only slightly $\left(0.50 \mathrm{mg} \mathrm{L}^{-1} \mathrm{O}_{2}, 7.7 \% \mathrm{O}_{2}\right)$, so the microbial community does not change drastically. In this site, the microorganisms found in SC-1, i.e., Acidithiobacillus (16.2\%), the putative sulfate-reducing Deltaproteobacterium (15.9\%), both Thermoplasmatales archaea (OTU_SC0008; 10.9\% and OTU SC0010;8.9\%) and the Sulfobacillus (6.9\%), are maintained in a major proportion. At this sampling point, it was also possible to characterize the microbiota in the sediments which consisted of coarse sand. The most abundant microorganism in all the sediment samples at SC-2 was an unclassified Anaerolineae bacterium (OTU_SC0006) distantly related to members of the genera Anaerolinea (89.8\% similar to Anaerolinea thermolimosa), Ornatilinea (88.0\% similar to Ornatilinea apprima), and Caldilinea ( $85.5 \%$ similar to Caldilinea aerophila). Members of these genera of the Chloroflexi phylum are reported as chemoorganoheterotrophic organisms, which thrive in very diverse habitats such as hot spring aquifers [58] or anaerobic wastewater sludge [59, 60]. Interestingly, we could also observe the presence of members of the genus Geothrix in the sediments of sampling point 2 (OTU_SC0021, $1.4 \%$ of relative abundance in SC-2S1, 8.2\% in SC-2S2 and 8.1\% in SC-2S3). Only one species from this genus, Geothrix fermentans, has been isolated to date [61]. It is a strict anaerobe capable to oxidize a wide variety of organic acids with ferric iron serving as the sole electron acceptor [59]. The observed Geothrix organisms could play a very important role in the sediments of the San Cayetano ecosystem, not only by the oxidation of organic matter but also in the dissolution of ferric iron. This idea is consistent with the iron detected in the sediments of sampling point 2 ( $8 \mathrm{~g} \mathrm{~kg}^{-1}$; see Table 2$)$. By doing so, the ferrous iron produced in the reduction process (mediated by Geothrix) becomes soluble and available for iron-oxidizing bacteria along the river course. Other microorganisms related to iron metabolism (e.g., genera Geobacter, Leptospirillum, Ferritrophicum) were detected in small amounts $(<1 \%)$ in the waters and sediments of SC-2.

Besides one of the Thermoplasmatales found also in the water sample (OTU_SC0008), another archaeon of the same order appeared as highly abundant in the sediments of SC-2 (OTU_SC0004; Fig. 5). Albeit also belonging to an unclassified species, 16S rDNA sequence shows high (99.2\%) similarity to those environmental OTUs obtained from the Kamchatkan hot springs (NCBI accession JF317816) or the sulfuric ponds of the Tatung Volcano area in Taiwan (NCBI accession FJ797335). The most closely related isolates OTU are those of the Picrophilus genus $(90.7 \%$ similarity to both $P$. torridus and $P$. oshimae) [56]. These microorganisms represent the most acidophilic organisms known, with the ability to survive at a $\mathrm{pH}$ around $0[56,62]$. Strains of this species were first isolated from a dry solfataric field in Japan [62]. 
Thus, it is possible that both Thermoplasmatales archaea take some part in the metabolism of sulfur in the sediments at this sampling point.

In summary, in the hypoxic zone of San Cayetano, we see microbes that are known for using sulfate and oxidized minerals as electron acceptors for their metabolism and can promote iron and sulfur cycling. The presence of iron- and sulfur-oxidizing microorganisms characteristic of ARD sites in San Cayetano's hypoxic source does seem contradictory until one realizes that the spring does have a meteoric water contribution and the aquifer recharge zone is on the slope of an active volcano. The fact that sulfate concentrations remain high could indicate that the ecosystem is not limited by the availability of electron acceptors, which would be consistent with the low amounts of dissolved organic carbon that are characteristic of hydrothermal fluids [63]. Instead, organisms such as Sulfobacillus and Acidithiobacillus or some Deltaproteobacteria could be fixing inorganic carbon [64-66], which could in turn be used by heterotrophs such as Cuniculiplasma as it has been described elsewhere [67]. Under this hypothesis of carbon deprivation, hydrogen would be the most likely energy source driving autotrophy in the hypoxic zone of San Cayetano. Indeed, the OTUs detected in that region belonged to known hydrogenotrophic taxa $[66,68,69]$ and high hydrogen concentrations are typical of hydrothermal fluids, including those in Costa Rica [70].

At the third sampling point $(30 \mathrm{~m}$ from the source, $20 \mathrm{~m}$ after a small waterfall), there is a significant change in the oxygen content $\left(3.77 \mathrm{mg} \mathrm{L}^{-1} \mathrm{O}_{2} ; 58 \% \mathrm{O}_{2}\right.$ saturation) as well as in the microbial community. Interestingly, the water sample (SC-3) is dominated by two Gammaproteobacteria accounting for more than $55 \%$ of the microbial community: a bacterium of the genus Ferritrophicum (OTU_SC0007; $33.2 \%$ ) where members are characterized by their capability of metabolizing iron compounds and an unclassified Burkholderiaceae (OTU_SC0001; 25.1\%) (Fig. 5). Of the genus Ferritrophicum, only one species (F. radicicola) has been reported. This corresponds to a neutrophilic bacterium, which uses ferrous iron as an energy source for lithotrophic growth. Remarkably, this microaerophilic bacterium was isolated from a plant growing in an acid mine drainage system [71]. The presence of Ferritrophicum at site SC-3 is puzzling because it is reported as a neutrophilic iron oxidizer. We reassessed the site and found that water runoff from nearby meadows can join the main stream at this point and this is an area of high rainfall. On the other hand, species of the Burkholderiaceae family occupy various ecological niches and perform very diverse metabolic functions (e.g., nitrogen fixation and aromatic compound catabolism) [72]. Therefore, it is difficult to assign a specific role to this generalist Betaproteobacterium in the San Cayetano VARD. The Acidithiobacillus and the two
Thermoplasmatales observed in the waters of SC-2 were also present at this sampling point, however, in lower relative 16S rRNA gene abundance (Acidithiobacillus 1.9\%; Thermoplasmatales archaea (OTU_SC0008; $4.7 \%$ and OTU SC $0010 ; 4.5 \%)$.

At SC-3 decomposing tree branches and leaves accumulate at the bottom of the creek and there was the first hint of a light tan organic layer on top of the gravel bed. The sediments of SC-3 showed the presence of the same Burkholderiaceae bacterium (OTU_SC0001) found in the water sample, as well as the Thermoplasmatales archaea (OTU_SC0004 and OTU_SC0008, respectively) found in the sediments of SC-2 (Fig. 5). The presence of these two archaea suggests their capacity to adapt to a wide range of oxygen conditions. In addition, we observed a high relative abundance of a Gammaproteobacterium that clusters within the Acidithiobacillaceae group RCP1-48 (OTU_SC0009). Members from this group have been previously detected in the sediments of other ARD habitats like Tinto river [3] or the Los Rueldos mercury underground mine in Spain [73], and it has been suggested that they could have an important role in the oxidation of iron and sulfur compounds [73]. Besides those microorganisms, the sediments host a member of the genus Leptospirillum (OTU_SC0003), and the same Ferritrophicum sp. found in the water sample. Particularly, the presence of Leptospirillum has been widely reported in $\mathrm{ARD}$ environments where it catalyzes ferrous iron oxidation, accelerating ferric iron-mediated oxidative dissolution of sulfide minerals and thus the formation of ARD [74]. Due to their extraordinary characteristics, Leptospirillum species have been used throughout the world in industrial bioleaching operations $[75,76]$. In summary, at sampling point SC-3, we observe an important increase of heterotrophic and ironoxidizing bacteria, while anaerobic sulfur oxidizers decreased (compared to samples SC-1 and SC-2). This observation also correlates with the increase of the oxygen concentration at SC3 (see Table 1 and Fig. 4). The abundance of ferrous iron produced by rock dissolution and the excess acid from magmatic sources set the stage here for iron-oxidizing acidophiles to appear in San Cayetano. Also, heterotrophic microbes begin to capitalize on the availability of organic matter from the adjacent forest and meadows carried into the stream by the rain. Even though dissolved organic carbon (Corg) measurements are required to properly validate the function of heterotrophic microbes in San Cayetano, Fig. 2 shows decomposing organic matter and even underwater mosses down the creek.

Finally, the sampling points four and five are representative of the stream steady-state characteristics and are located $600 \mathrm{~m}$ and $900 \mathrm{~m}$ from the origin, respectively. Both have similar high oxygen contents and very similar microbial composition (Figs. 4 and 5). The oxygen content was $5.85 \mathrm{mg} \mathrm{L}^{-1}$ $\mathrm{O}_{2}\left(82 \% \mathrm{O}_{2}\right.$ saturation) and $6.06 \mathrm{mg} \mathrm{L}^{-1} \mathrm{O}_{2}\left(81 \% \mathrm{O}_{2}\right)$, respectively. The microbial community in those waters is 
dominated by the same Burkholderiaceae bacterium found in SC-3 (36.9\% in SC-4 and 30.0\% in SC-5), followed by the Leptospirillum sp. present in the sediments of SC-3 (18.3\% in SC-4 and $11.4 \%$ in SC-5). In addition, we detected large quantities of the heterotrophic acidophilic Acidithrix (OTU_SC0005; $7.58 \%$ in SC-4 and $11.88 \%$ in SC-5). Acidithrix ferrooxidans is the only species from this genus that has been described to date. This bacterium carries out dissimilatory oxidation of ferrous iron under aerobic conditions and the reduction of ferric iron under micro-aerobic and anaerobic conditions [77]. Given the oxic conditions of SC-4 and SC-5, it can be assumed that the Acidithrix detected in both water samples contributes to the oxidation of ferrous iron. These conditions are very appropriate also for the obligate aerobe Leptospirillum sp. (see above) and for other ironoxidizing bacteria present in these samples in minor abundance (i.e., Ferrovum spp.). The presence of high levels of iron at sediments of sampling points 4 and 5 (Table 2; i.e., SC-4S $220 \pm 32 \mathrm{~g} \mathrm{~kg}^{-1}$ and SC-5S $293 \pm 43 \mathrm{~g} \mathrm{~kg}^{-1}$ ) is consistent with the large number of iron oxidizers found in the waters. We hypothesize that the activity of iron-oxidizing microorganisms favors the precipitation of ferric minerals, so the levels of iron in the sediments are increased $\sim 30$ times compared to that observed in hypoxic conditions (point SC-2S in Table 2; i.e., $8 \mathrm{~g} \mathrm{~kg}^{-1}$ of iron). In addition, other heterotrophic bacteria from the genera Trichococcus and Acidocella were found in the water from sampling points SC-4 and SC-5, respectively.

Similar to the water samples, the sediments obtained from SC-4 and SC-5, showed a similar microbial composition among them (Fig. 5). Here, the beige-colored organic deposit becomes thicker and slowly gives rise to a cover of underwater moss as seen in Fig. 2. The most prominent organism in both samples is a Gammaproteobacterium of the genus Metallibacterium (OTU_SC0002). Once again, this genus has only one reported species (M. scheffleri) and has been very poorly studied. Among the few known metabolic functions of this species, it is known that it is capable of reducing ferric iron, but does not oxidize ferrous iron in anoxic conditions [78]. This is also consistent with the high levels of iron found in the sediments of these sampling points (see Table 2). We hypothesize that iron precipitates as a ferric mineral so that iron(III) can be used by iron-reducing microorganisms such as members of the genus Metallibacterium. We also observed a high abundance of some of the microorganisms identified in the water samples from sampling points SC-4 and SC-5, such as the Burkholderiaceae bacterium, Acidithrix sp., Leptospirillum sp., and Ferrovum sp. Other microorganisms found in the sediments of SC-5 were a Gammaproteobacterium (OTU_SC0013) from the uncultured group KF-JG30-C25

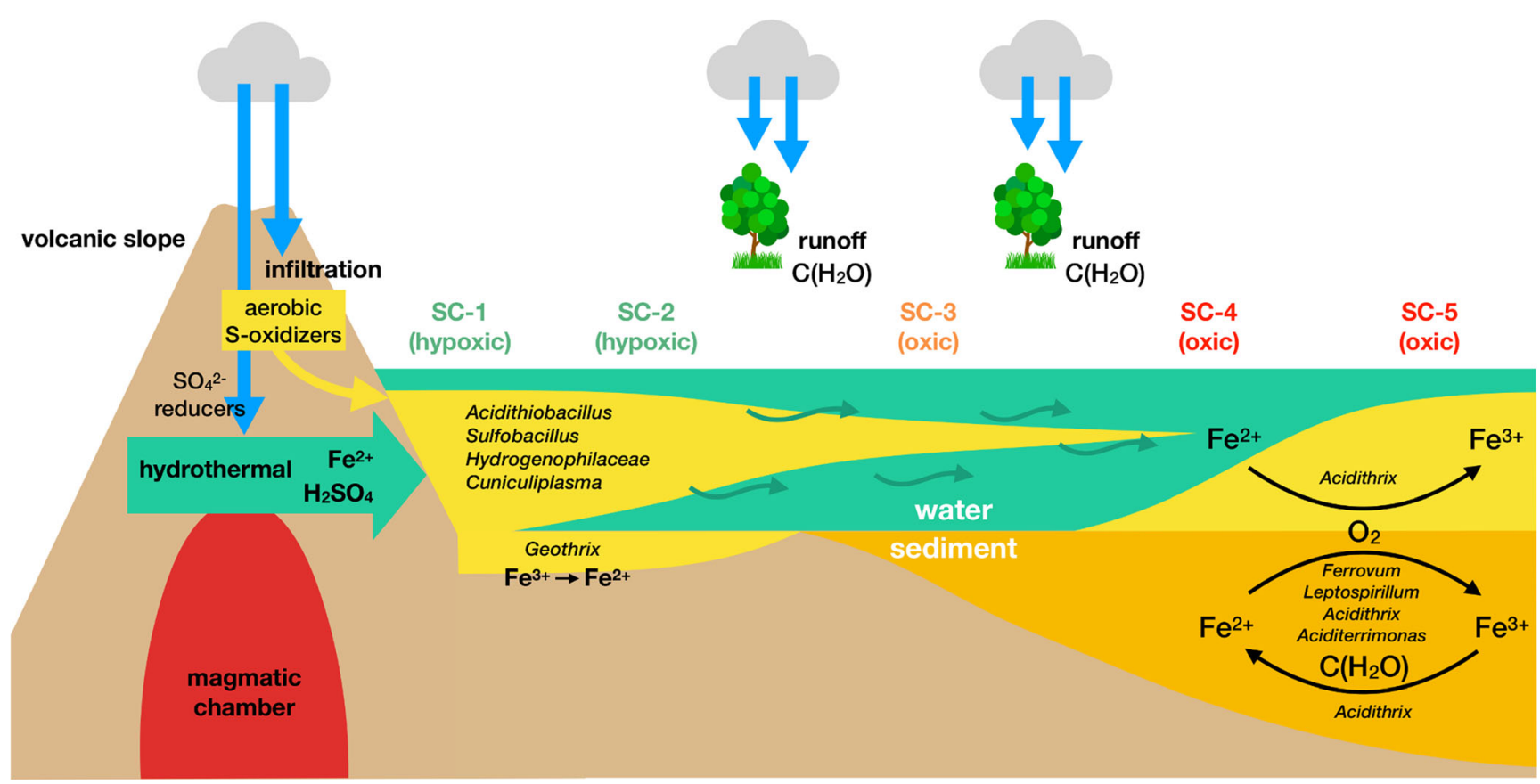

Fig. 6 Cartoon of the biogeochemical processes and important microorganisms in San Cayetano volcanic influenced acid rock drainage (VARD). Hydrothermal water (colored blue-green representing its ferrous,, $\mathrm{Fe}^{+2}$ iron content from rock dissolution) mixes with infiltrated meteoric water on the volcanic slope (colored light yellow and containing the aquifer microbes) and exits the ground inside the forest. The source's microbes dominate in the hypoxic slow-flowing pond but the creek's iron oxidizers start taking over after the waterfall at SC-3.
Increasing oxygen content allows for more iron oxidation metabolism, represented by a widening yellow band in the water, and sediment iron cycling represented by a widening orange band. The sampling site label colors represent the progression from ferrous to ferric iron species and parallel the oxygen content of the water. Finally, water runoff along the creek inputs organic matter resulting in a mixture of lithotrophic acidophiles and heterotrophic microorganisms 
and another Actinobacterium (OTU_SC0020) whose closest isolate ( $91.4 \%$ similarity) is the heterotrophic ferric iron reducer Aciditerrimonas ferrireducens [79]. Specifically, members of KF-JG30-C25 group have been detected in ARD habitats such as the uranium mining waste pile at Johanngeorgenstadt in Germany [80]. Just as in ARD rivers like the Tinto river, here, we observe a much more complex system with active iron oxidation on the top of the sediment and in the water column occurring simultaneously with iron and sulfur cycling within the sediment due to the availability of reduced carbon.

\section{Conclusions}

The structure of the microbial community in San Cayetano undergoes important changes as a function of the oxygen gradient observed in the distinct water samples. At the origin of the river (SC-1 and SC-2), the microbial profile is dominated by putative anaerobic, sulfur-oxidizing microorganisms (such as Sulfobacillus sp., Acidithiobacillus sp.), a putative sulfatereducing Deltaproteobacterium, and a Hydrogenophilaceae bacterium. In the origin of San Cayetano, we hypothesize that the main electron acceptor is sulfate (see Fig. 6) and therefore, we find as the dominant microorganism a putative sulfatereducing Deltaproteobacterium. Furthermore, the recently deposited volcanic materials at the aquifer recharge area are a likely habitat for sulfur oxidizers (such as Sulfobacillus sp., Acidithiobacillus sp.). At the third sampling point (SC-3), the oxygen content increases eightfold (from 0.40 to $3.77 \mathrm{mg} \mathrm{L}^{-1}$ ), also generating a drastic change in the microbial community of both waters and sediments. Most of the sulfuroxidizing taxa found at the origin of the river are substituted by iron oxidizers (Leptospirillum sp.) and heterotrophic microorganisms (Burkholderiaceae bacterium). After $600 \mathrm{~m}$ downstream from the origin of San Cayetano, the river is completely oxygenated. Consequently, the last two samples (SC-4 and SC-5) are totally dominated by aerobic microorganisms, mostly representing heterotrophic metabolism (Burkholderiaceae bacterium, Trichococcus sp. Acidocella sp.) or iron oxidation (Leptospirillum sp., Acidithrix sp., Ferrovum spp.) (Fig. 6). Ferrous iron input from the deep hydrothermal source becomes now the main electron source for lithotrophs but input of reduced carbon from the surrounding slopes allows for sulfur and iron reducers to appear in the sediments, a role that in Tinto river is assumed by its extensive eukaryotic biomass [81]. In summary, San Cayetano shows how the key actors responsible for the iron and sulfur cycle change as a function of oxygen content.

Perhaps the main difference between the San Cayetano volcanic spring and other natural, pristine ARD sites is that in the latter, sulfuric acid and metal content are a consequence of the microbial oxidation of sulfide minerals. In VARD sites, both the acid and metallic content are produced abiotically at high temperatures, with the later incorporation of chemolitotrophic microbes and with little or no sulfide available initially. Specialized pyrite-oxidizing microorganisms are therefore not as dominant as the iron oxidizers. Water infiltration from the volcanic slope (or from volcanic lakes in other cases) is likely the source of some of the ARD-like microbes as observed in San Cayetano, and we can assume it will be dominated by sulfur oxidizers characteristic of volcanic environments. These factors seem to separate iron oxidation from sulfur oxidation processes in time and space, and therefore, we can expect to find different proportions of the associated microbes according to the local geology and contributions of hydrothermal and meteoric water sources.

We will continue the study of unexplored extreme sites in Costa Rica, in order to understand the role of microbiota in these environments. Some are reasonably accessible but others will require considerable exploration and fieldwork. However, their potential as a knowledge source will surely pay. How variable are the extreme sites in Costa Rica in terms of their geochemical characteristics? How wide is the microbial diversity in these environments? Are there patterns between sites that can relate geology, geochemistry, and microbiota? These are some of the questions that our research group tries to answer taking advantage of the many existing ecosystems in Costa Rica.

Acknowledgments We thank Carlos Rodriguez of Centro de Investigación en Contaminación Ambiental (CICA-UCR) for the help with the chemical analysis. We also are grateful to Solange Voysest for help with the design of some figures.

Funding Information This work was supported by The Vice-rectory of Research of Universidad de Costa Rica (project number VI 809-B6-524), the Costa Rican Ministry of Science, Technology and Telecommunication (MICITT) and Federal Ministry of Education and Research (BMBF) (project VolcanZyme contract No FI-255B-17), and the ERC grant IPBSL (ERC250350-IPBSL). MM acknowledges government funding from the Transitorio I of the National Law 8488 for Emergencies and Risk Prevention in Costa Rica. F.P-S. is supported by grant IJC2018-035180-I from the Spanish Ministry of Science and Innovation.

\section{References}

1. Baker BJ, Banfield JF (2003) Microbial communities in acid mine drainage. FEMS Microbiol Ecol 44:139-152

2. Johnson DB, Bacelar-Nicolau P, Okibe N, Thomas A, Hallberg KB (2009) Ferrimicrobium acidiphilum gen. nov., sp. nov. and Ferrithrix thermotolerans gen. nov., sp. nov.: heterotrophic, ironoxidizing, extremely acidophilic actinobacteria. Int J Syst Evol Microbiol 59:1082-1089

3. Sánchez-Andrea I, Rodríguez N, Amils R, Sanz JL (2011) Microbial diversity in anaerobic sediments at Río Tinto, a naturally acidic environment with a high heavy metal content. Appl Environ Microbiol 77:6085-6093

4. Arce-Rodríguez A, Puente-Sánchez F, Avendaño R, Martínez-Cruz M, de Moor JM, Pieper DH, Chavarría M (2019) 
Thermoplasmatales and sulfur-oxidizing bacteria dominate the microbial community at the surface water of a $\mathrm{CO}_{2}$-rich hydrothermal spring located in Tenorio Volcano National Park, Costa Rica. Extremophiles 23:177-187

5. Gadanho M, Libkind D, Sampaio JP (2006) Yeast diversity in the extreme acidic environments of the Iberian Pyrite Belt. Microb Ecol 52:552-563

6. González-Toril E, Santofimia E, Blanco Y, López-Pamo E, Gómez MJ, Bobadilla M, Cruz R, Palomino EJ, Aguilera Á (2015) Pyrosequencing-based assessment of the microbial community structure of Pastoruri glacier area (Huascarán National Park, Perú), a natural extreme acidic environment. Microb Ecol 70: 936-947

7. Dold B, Gonzalez-Toril E, Aguilera A, Lopez-Pamo E, Cisternas ME, Bucchi F, Amils R (2013) Acid rock drainage and rock weathering in Antarctica: important sources for iron cycling in the Southern Ocean. Environ Sci Technol 47:6129-6136

8. González-Toril E, Llobet-Brossa E, Casamayor EO et al (2003) Microbial ecology of an extreme acidic environment, the Tinto River. Appl Environ Microbiol 69:4853-4865

9. López-Archilla AI, Gérard E, Moreira D et al (2004) Macrofilamentous microbial communities in the metal-rich and acidic river Tinto Spain. FEMS Microbiol Lett 235:221-228

10. García-Moyano A, González-Toril E, Aguilera Á, Amils R (2012) Comparative microbial ecology study of the sediments and the water column of the Río Tinto, an extreme acidic environment. FEMS Microbiol Ecol 81:303-314

11. Sánchez-Andrea I, Knittel K, Amann R, Amils R, Sanz JL (2012) Quantification of Tinto River sediment microbial communities: importance of sulfate-reducing bacteria and their role in attenuating acid mine drainage. Appl Environ Microbiol 78:4638-4645

12. Fernández-Remolar DC, Rodriguez N, Gomez F (2003) Geological record of an acidic environment driven by iron hydrochemistry: the Tinto River system. J Geophys Res 108:5080

13. Amils R, Fernández-Remolar D, the IPBSL Team (2014) Río Tinto: a geochemical and mineralogical terrestrial analogue of Mars. Life 4:511-534

14. Arce-Rodríguez A, Puente-Sánchez F, Avendaño R, Libby E, Rojas L, Cambronero JC, Pieper DH, Timmis KN, Chavarría M (2017) Pristine but metal-rich Río Sucio (Dirty River) is dominated by Gallionella and other iron-sulfur oxidizing microbes. Extremophiles 21:235-243

15. Urbieta M, Porati G, Segretín A, González-Toril E, Giaveno M, Donati E (2015) Copahue geothermal system: a volcanic environment with rich extreme prokaryotic biodiversity. Microorganisms 3:344-363

16. Johnson DB, Okibe N, Roberto FF (2003) Novel thermos-acidophilic bacteria isolated from geothermal sites in Yellowstone National Park: physiological and phylogenetic characteristics. Arch Microbiol 180:60-68

17. Melton ED, Swanner ED, Behrens S, Schmidt C, Kappler A (2014) The interplay of microbially mediated and abiotic reactions in the biogeochemical Fe cycle. Nat Rev Microbiol 12:797-808

18. Castellón E, Martínez M, Madrigal-Carballo S, Arias ML, Vargas WE, Chavarría M (2013) Scattering of light by colloidal aluminosilicate particles produces the unusual sky-blue color of Río Celeste (Tenorio volcano complex, Costa Rica). PLoS One 8:e75165

19. González-Toril E, Aguilera A, Rodriguez N, Fernández-Remolar D, Gómez F, Diaz E, García-Moyano A, Sanz JL, Amils R (2010) Microbial ecology of Río Tinto, a natural extreme acidic environment of biohydrometallurgical interest. Hydrometallurgy 104:329 333

20. Bohorquez LC, Delgado-Serrano L, López G, Osorio-Forero C, Klepac-Ceraj V, Kolter R, Junca H, Baena S, Zambrano MM (2012) In-depth characterization via complementing culture- independent approaches of the microbial community in an acidic hot spring of the Colombian Andes. Microb Ecol 63:103-115

21. Camarinha-Silva A, Jáuregui R, Chaves-Moreno D, Oxley APA, Schaumburg F, Becker K, Wos-Oxley ML, Pieper DH (2014) Comparing the anterior nare bacterial community of two discrete human populations using Illumina amplicon sequencing. Environ Microbiol 16:2939-2952

22. Schulz C, Schütte K, Koch N, Vilchez-Vargas R, Wos-Oxley ML, Oxley APA, Vital M, Malfertheiner P, Pieper DH (2018) The active bacterial assemblages of the upper GI tract in individuals with and without Helicobacter infection. Gut 67:216-225

23. Cole JR, Wang Q, Fish JA et al (2014) Ribosomal database project: data and tools for high throughput rRNA analysis. Nucleic Acids Res 42:633-642

24. Schloss PD, Westcott SL, Ryabin T, Hall JR, Hartmann M, Hollister EB, Lesniewski RA, Oakley BB, Parks DH, Robinson CJ, Sahl JW, Stres B, Thallinger GG, van Horn DJ, Weber CF (2009) Introducing mothur: open-source, platform-independent, community-supported software for describing and comparing microbial communities. Appl Environ Microbiol 75:7537-7541

25. Yilmaz P, Parfrey LW, Yarza P, Gerken J, Pruesse E, Quast C, Schweer T, Peplies J, Ludwig W, Glöckner FO (2014) The SILVA and "All-Species Living Tree Project (LTP)" taxonomic frameworks. Nucleic Acids Res. 42:D643-D648

26. Pruesse E, Peplies J, Glöckner FO (2012) SINA: accurate highthroughput multiple sequence alignment of ribosomal RNA genes. Bioinformatics 28:1823-1829

27. Pruesse E, Quast C, Knittel K, Fuchs BM, Ludwig W, Peplies J, Glockner FO (2007) SILVA: a comprehensive online resource for quality checked and aligned ribosomal RNA sequence data compatible with ARB. Nucleic Acids Res 35:7188-7196

28. Yarza P, Yilmaz P, Pruesse E, Glöckner FO, Ludwig W, Schleifer KH, Whitman WB, Euzéby J, Amann R, Rosselló-Móra R (2014) Uniting the classification of cultured and uncultured bacteria and archaea using 16S rRNA gene sequences. Nat Rev Microbiol 12: 635-645

29. Altschul SF, Madden TL, Schäffer AA, Zhang J, Zhang Z, Miller W, Lipman DJ (1997) Gapped BLAST and PSI-BLAST: a new generation of protein database search programs. Nucleic Acids Res 25:3389-3402

30. Core Team R (2017) R: A language and environment for statistical computing. R Foundation for Statistical Computing, Vienna, Austria http://www.R-project.org/

31. Oksanen J, Blanchet FG, Friendly M, et al (2017) Vegan: Community Ecology Package. R package Version 2.4-3. https:// CRAN.R project.org/package=vegan

32. La Gaceta (2017) Decreto $N^{\circ} 33903-M I N A E-S$ El Presidente de la República El Ministro de Ambiente y Energía y la Ministra de Salud. $\mathrm{N}^{\circ} 178$

33. Vaselli O, Tassi F, Duarte E, Fernandez E, Poreda RJ, Huertas AD (2010) Evolution of fluid geochemistry at the Turrialba volcano (Costa Rica) from 1998 to 2008. Bull Volcanol 72:397-410

34. Alvarado GE, Vega AE (2013) The Cervantes lava flow geomorphology, Irazú volcano (Costa Rica): description of the Central America's greater lava flow field. Rev Geol Amer Central 48:99 118

35. Ruprecht P, Plank T (2013) Feeding andesitic eruptions with a high-speed connection from the mantle. Nature 500:68-72

36. Piazza AD, Vona A, Mollo S et al (2019) Unsteady magma discharge during the "El Retiro" subplinian eruption (Turrialba volcano, Costa Rica): insights from textural and petrological analyses. J Volcanol Geotherm Res 371:101-115

37. Kusakabe M, Komoda Y, Takano B, Abiko T (2000) Sulfur isotopic effects in the disproportionation reaction of sulfur dioxide in hydrothermal fluids: implications for the $\delta^{34} \mathrm{~S}$ variations of 
dissolved bisulfate and elemental sulfur from active crater lakes. J Volcanol Geotherm Res 97:287-307

38. Reagan M, Duarte E, Soto, et al (2006) The eruptive history of Turrialba volcano, Costa Rica, and potential hazards from future eruptions In Rose WI, Bluth GJS, Carr MJ et al Volcanic Hazards in Central América: Geological Society of America Special Paper 412, 235-257

39. Marcucci EC, Hynek BM (2014) Laboratory simulations of acidsulfate weathering under volcanic hydrothermal conditions: implications for early Mars. J Geophys Res 119:679-703

40. Zimbelman DR, Rye RO, Breit GN (2005) Origin of secondary sulfate minerals on active andesitic stratovolcanoes. Chem Geol 215:37-60

41. Winch S, Mills HJ, Kostka JE, Fortin D, Lean DRS (2009) Identification of sulfate-reducing bacteria in methylmercury-contaminated mine tailings by analysis of SSU rRNA genes. FEMS Micro Ecol 68:94-107

42. Johnson DB, Joulian C, D'Hugues P et al (2008) Sulfobacillus benefaciens sp. nov., an acidophilic facultative anaerobic Firmicute isolated from mineral bioleaching operations. Extremophiles 12:789-798

43. Watling HR, Perrot FA, Shiers DW (2008) Comparison of selected characteristics of Sulfobacillus species and review of their occurrence in acidic and bioleaching environments. Hydrometallurgy 93: $57-65$

44. Norris PR, Clark DA, Owen JP, Waterhouse S (1996) Characteristics of Sulfobacillus acidophilus sp. nov. and other moderately thermophilic mineral-sulphide-oxidizing bacteria. Microbiology 142:775-783

45. Pina PS, Oliveira VA, Cruz FLS, Leão VA (2010) Kinetics of ferrous iron oxidation by Sulfobacillus thermosulfidooxidans. Biochem Eng J 51:194-197

46. Suzuki I, Takeuchi TL, Yuthasastrakosol TD, Oh JK (1990) Ferrous iron and sulfur oxidation and ferric iron reduction activities of Thiobacillus ferrooxidans are affected by growth on ferrous iron, sulfur, or a sulfide ore. Appl Environ Microbiol 56:1620-1626

47. Pronk JT, Johnson DB (1992) Oxidation and reduction of iron by acidophilic bacteria. Geomicrobiol J 10:79

48. Menzel P, Gudbergsdóttir SR, Rike AG, Lin L, Zhang Q, Contursi P, Moracci M, Kristjansson JK, Bolduc B, Gavrilov S, Ravin N, Mardanov A, Bonch-Osmolovskaya E, Young M, Krogh A, Peng $X$ (2015) Comparative metagenomics of eight geographically remote terrestrial hot springs. Microb Ecol 70:411-424

49. Kojima H, Watanabe M, Fukui M (2017) Sulfuritortus calidifontis gen. Nov., sp. nov., a sulfur oxidizer isolated from a hot spring microbial mat. Int J Syst Evol Microbiol 67:1355-1358

50. Boden R, Hutt LP, Rae AW (2017) Reclassification of Thiobacillus aquaesulis (Wood \& Kelly, 1995) as Annwoodia aquaesulis gen. nov., comb. nov., transfer of Thiobacillus (Beijerinck, 1904) from the Hydrogenophilales to the Nitrosomonadales, proposal of Hydrogenophilalia class. nov. within the 'Proteobacteria', and four new families within the orders Nitrosomonadales and Rhodocyclales. Int J Syst Evol Microbiol 67:1191-1205

51. Auernik KS, Cooper CR, Kelly RM (2008) Life in hot acid: pathway analyses in extremely thermoacidophilic archaea. Curr Opin Biotechnol 19:445-453

52. Golyshina OV, Lünsdorf H, Kublanov IV, Goldenstein NI, Hinrichs KU, Golyshin PN (2016) The novel extremely acidophilic, cell-wall-deficient archaeon Cuniculiplasma divulgatum gen. nov., sp. nov. represents a new family, Cuniculiplasmataceae fam. nov., of the order Thermoplasmatales. Int J Syst Evol Microbiol 66:332-340

53. Yasuda M, Oyaizu H, Yamagishi A, Oshima T (1995) Morphological variation of new Thermoplasma acidophilum isolates from Japanese hot springs. Appl Environ Microbiol 61:34823485
54. Segerer A, Langworthy TA, Stetter KO (1988) Thermoplasma acidophilum and Thermoplasma volcanium sp. nov. from Solfatara fields. Syst Appl Microbiol 10:161-171

55. Itoh T, Yoshikawa N, Takashina T (2007) Thermogymnomonas acidicola gen. nov., sp. nov., a novel thermoacidophilic, cell wallless archaeon in order Thermoplasmatales, isolated from a solfataric soil in Hakone Japan. Int J Syst Evol Microbiol 57:2557-2561

56. Schleper C, Puehler G, Holz I, Gambacorta A, Janekovic D, Santarius U, Klenk HP, Zillig W (1995) Picrophilus gen. nov., fam. nov.: a novel aerobic, heterotrophic, thermoacidophilic genus and family comprising archaea capable of growth around $\mathrm{pH}$ 0. J Bacteriol 177:7050-7059

57. Serour E, Antranikian G (2002) Novel thermoactive glucoamylases from thermoacidophilic archea Thermoplasma acidophilum, Picrophilus torridus and Picrophilus oshimae. Antonie Van Leeuwenhoek 81:73-83

58. Grégoire P, Bohli M, Cayol JL et al (2011) Caldilinea tarbellica sp. nov., a filamentous, thermophilic, anaerobic bacterium isolated from a deep hot aquifer in the Aquitaine Basin. Int J Syst Evol Microbiol 61:1436-1441

59. Sekiguchi Y, Yamada T, Hanada S et al (2003) Anaerolinea thermophila gen. Nov., sp. nov. and Caldilinea aerophila gen. nov., sp. nov., novel filamentous thermophiles that represent a previously uncultured lineage of the domain bacteria at the subphylum level. Int J Syst Evol Microbiol 53:1843-1851

60. Yamada T, Sekiguchi Y, Imachi H et al (2005) Diversity, localization, and physiological properties of filamentous microbes belonging to Chloroflexi subphylum I in mesophilic and thermophilic methanogenic sludge granules. Microbiology 71:7493-7503

61. Coates JD, Ellis DJ, Gaw CV et al (1999) Geothrix fermentans gen. nov., sp. nov., a novel Fe(III)-reducing bacterium from a hydrocarbon-contaminated aquifer. Int J Syst Bacteriol 49:1615-1622

62. Fütterer O, Angelov A, Liesegang H, Gottschalk G, Schleper C, Schepers B, Dock C, Antranikian G, Liebl W (2004) Genome sequence of Picrophilus torridus and its implications for life around pH 0. Proc Natl Acad Sci 101:9091-9096

63. Lang SQ, Butterfield DA, Lilley MD, Paul Johnson H, Hedges JI (2006) Dissolved organic carbon in ridge-axis and ridge-flank hydrothermal systems. Geochim Cosmochim Acta 70:3830-3842

64. Justice NB, Norman A, Brown CT, Singh A, Thomas BC, Banfield JF (2014) Comparison of environmental and isolate Sulfobacillus genomes reveals diverse carbon, sulfur, nitrogen, and hydrogen metabolisms. BMC Genomics 15:1107

65. Gale NL, Beck JV (1967) Evidence for the Calvin cycle and hexose monophosphate pathway in Thiobacillus ferrooxidans. J Bacteriol 94:1052-1059

66. Brysch K, Schneider C, Fuchs G, Widdel F (1987) Lithoautotrophic growth of sulfate-reducing bacteria, and description of Desulfobacterium autotrophicum gen. nov., sp. nov. Arch Microbiol 148:264-274

67. Golyshina OV, Kublanov IV, Tran H, Korzhenkov AA, Lünsdorf H, Nechitaylo TY, Gavrilov SN, Toshchakov SV, Golyshin PN (2016) Biology of archaea from a novel family Cuniculiplasmataceae (Thermoplasmata) ubiquitous in hyper acidic environments. Sci Rep 6:39034

68. Hedrich S, Johnson DB (2013) Aerobic and anaerobic oxidation of hydrogen by acidophilic bacteria. FEMS Microbiol Lett 349:40-45

69. Brandis A, Thauer RK (1981) Growth of Desulfovibrio species on hydrogen and sulphate as sole energy source. Microbiology 126: 249-252

70. Melián GV, Galindo I, Pérez NM, Hernández PA, Fernández M, Ramírez C, Mora R, Alvarado GE (2007) Diffuse emission of hydrogen from Poás Volcano, Costa Rica. América Central Pure Appl Geophys 164:2465-2487

71. Weiss JV, Rentz JA, Plaia T, Neubauer SC, Merrill-Floyd M, Lilburn T, Bradburne C, Megonigal JP, Emerson D (2007) 
Characterization of neutrophilic Fe(II)-oxidizing bacteria isolated from the rhizosphere of wetland plants and description of Ferritrophicum radicicola gen. nov. sp. nov., and Sideroxydans paludicola sp. nov. Geomicrobiol J 24:559-570

72. Compant S, Nowak J, Coenye T, Clément C, Ait Barka E (2008) Diversity and occurrence of Burkholderia spp. in the natural environment. FEMS Microbiol Rev 32:607-626

73. Mesa V, Gallego JLR, González-Gil R, Lauga B, Sánchez J, Méndez-García C, Peláez AI (2017) Bacterial, archaeal, and eukaryotic diversity across distinct microhabitats in an acid mine drainage. Front Microbiol 8:1756

74. Goltsman DSA, Dasari M, Thomas BC, Shah MB, VerBerkmoes NC, Hettich RL, Banfield JF (2013) New group in the Leptospirillum clade: cultivation-independent community genomics, proteomics, and transcriptomics of the new species "Leptospirillum Group IV UBA BS.". Appl Environ Microbiol 79:5384-5393

75. Sand W, Rohde K, Sobotke B, Zenneck C (1992) Evaluation of Leptospirillum ferrooxidans for leaching. Appl Environ Microbiol 58:85-92

76. Issotta F, Galleguillos PA, Moya-Beltrán A et al (2016) Draft genome sequence of chloride-tolerant Leptospirillum ferriphilum Sp-
$\mathrm{Cl}$ from industrial bioleaching operations in Northern Chile. Stand Genomic Sci 11:1-7

77. Jones RM, Johnson DB (2015) Acidithrix ferrooxidans gen. nov., sp. nov.; a filamentous and obligately heterotrophic, acidophilic member of the Actinobacteria that catalyzes dissimilatory oxidoreduction of iron. Res Microbiol 166:111-120

78. Ziegler S, Waidner B, Itoh T, Schumann P, Spring S, Gescher J (2013) Metallibacterium scheffleri gen. nov., sp. nov., an alkalinizing gammaproteobacterium isolated from an acidic biofilm. Int $\mathrm{J}$ Syst Evol Microbiol 63:1499-1504

79. Itoh T, Yamanoi K, Kudo T, Ohkuma M, Takashina T (2011) Aciditerrimonas ferrireducens gen. nov., sp. nov., an iron-reducing thermoacidophilic actinobacterium isolated from a solfataric field. Int J Syst Evol Microbiol 61:1281-1285

80. Selenska-Pobell S (2002) Chapter 8 diversity and activity of bacteria in uranium waste piles. Radioactivity in the environment 2:225254

81. Aguilera A, Manrubia SC, Gómez F et al (2006) Eukaryotic community distribution and its relationship to water physicochemical parameters in an extreme acidic environment, Río Tinto (Southwestern Spain). Appl Environ Microbiol 72:5325-5330 